\title{
Numerical Simulation Study on Construction Effect of Top-Down Construction Method of Suspended Diaphragm Wall for Deep and Large Foundation Pit in Complex Stratum
}

\author{
Yunhui Zhu, ${ }^{1}$ Fuxue Sun $\mathbb{D}^{2},{ }^{2}$ Mingqing Liu, ${ }^{1}$ Qifeng Liu, ${ }^{3}$ Xiaochun Li, ${ }^{4}$ and Gang Ge \\ ${ }^{1}$ Wenzhou University of Technology, Wenzhou 325035, China \\ ${ }^{2}$ Wenzhou University, Wenzhou 325035, China \\ ${ }^{3}$ Wenzhou Railway and Rail Transit Investment Co., Ltd, Wenzhou 325035, China \\ ${ }^{4}$ Shanghai Tunnel Engineering Co., Ltd, Shanghai 200000, China
}

Correspondence should be addressed to Fuxue Sun; sunfuxue@163.com

Received 31 July 2021; Revised 6 January 2022; Accepted 21 January 2022; Published 7 March 2022

Academic Editor: Jian Ji

Copyright (C) 2022 Yunhui Zhu et al. This is an open access article distributed under the Creative Commons Attribution License, which permits unrestricted use, distribution, and reproduction in any medium, provided the original work is properly cited.

In order to study the deformation of a diaphragm wall and the settlement of surrounding soil under the complicated conditions of the deep and soft soil layer, which is underlying inclined rock and top-down construction method, the construction scheme of suspended diaphragm wall based on the engineering practice of Oujiang North Estuary deep and large foundation pit of Wenzhou S2 railway is proposed, and the research method of numerical simulation is adopted in this article. By using Midas GTS finite element software, a three-dimensional model of deep and large foundation pit excavation with top-down construction method is established, and the internal force, deformation, and surface settlement of surrounding soil of suspended diaphragm wall with different depths into rock (1 m, $2 \mathrm{~m}$, and $4 \mathrm{~m}$ ) are analyzed. Furthermore, the optimization simulation research on the anchor locking scheme is carried out for the determined footed diaphragm wall. Similarly, the anchor locking scheme at a depth of $1 \mathrm{~m}$ into the interface between soil and rock is selected as the supporting scheme of the footed diaphragm wall through the simulation results. The research results of this article can guarantee the safety of diaphragm wall construction of deep and large foundation pit in complex stratum.

\section{Introduction}

At present, deep foundation pit engineering is more and more widely applied, and the depth of foundation pit is also becoming deeper and deeper. Most of the deep foundation pits must be supported during the construction period. The purpose of foundation pit support is to ensure the safety of the surrounding environment of the foundation pit and the construction process of the underground structure [1]. The temporary enclosure, support, or reinforcement measures taken around the working face of the basement create favorable conditions for the construction of the underground structure and ensure a good working environment for the underground construction.

In the 1920s-1930s, Germany, France, and Italy obtained the initial patent of diaphragm wall through practical certification and adopted the "pile wall integration" technology to reduce the thickness of the basement exterior wall and the area of the foundation pit. The design comprehensively considers the load transfer structure of waterproof [2] and diaphragm wall and checks the strength and durability under different loads through different stages of foundation pit construction and external factors [3], such as earthquakes [4]. In 1950, Italy built the first pile row diaphragm wall reservoir dam, and later in Milan metro project, the subway retaining wall has been built in pebble foundation [5], which shows the good advantages of diaphragm wall technology and further promotes the development of diaphragm wall and "pile wall integration" technology. Since then, Germany, France, Japan, the United States, and other countries have introduced diaphragm wall and "pile wall integration" technology [6] and continuously improved and 
developed. At present, the technology of diaphragm wall in Japan is at the leading level in the world. The diaphragm wall with the deepest depth of $140 \mathrm{~m}$ and thickness of $2.8 \mathrm{~m}$ has been built, and the deep well with an inner diameter of $144 \mathrm{~m}$ and a depth of $110.1 \mathrm{~m}$ has been built.

At present, the foundation pit engineering is developing in the direction of large scale, large depth, tight construction period, and short distance [7]. The foundation pit support methods are diversified. Various support forms can be seen in the same foundation pit. Soil nailing wall support and pile row support are combined, and slope excavation is combined with the diaphragm wall. Because the urban land is more and more expensive and the urban traffic pressure and the population are increasing, the top-down construction method for foundation pit design has become the first choice for the foundation pit excavation adjacent to the urban underground pipeline and subway. The top-down construction method for foundation pit design is suitable for large-area and deep foundation pits. It can simultaneously construct the superstructure, effectively shorten the construction period, save the cost, and control the deformation of the foundation pit and soil outside the pit. With the further improvement of the construction accuracy of column piles in underground structures, more and more civil engineers favor the reverse method design for constructing basement foundation pits of high-rise buildings, and many typical projects have emerged $[8,9]$. At the same time, many scholars have conducted in-depth research on reverse practice and achieved some important results.

$\mathrm{Ou}$ et al. [10] conducted field measurement on the foundation pit excavated by the top-down construction method, analyzed the data, and concluded that the horizontal displacement of soil close to the diaphragm wall is similar to that of the wall. Long [11] conducted a large number of field measurements by studying the relationship between foundation pit deformation and excavation depth with different soft soil thicknesses between the bottom-up construction method and the top-down construction method. It is concluded that the top-down construction method can reduce the deformation of the foundation pit. Gong et al. [12] proposed that the top-down construction method avoids repeated labor such as dismantling and replacing supports, saves resources and construction cost, and requires a small site during construction, which brings many conveniences to the construction. Kung [13] collected and summarized the actual construction cases of 26 foundation pits in the Taipei silty clay area. The analysis results show that the horizontal displacement of diaphragm wall in bottom-up construction method foundation pit is 1.28 times that in top-down construction method foundation pit under similar engineering conditions. Regardless of the thermal shrinkage effect of concrete floor, the average horizontal displacement of diaphragm wall in bottom-up construction method foundation pit is 1.1 times that in the top-down construction method. Aye et al. [14] used the finite element software PLAXIS to analyze the influence of the underground passage constructed by the top-down construction method in Bangkok on the upper existing overpass, obtained the stratum calculation parameters through the inversion analysis, calculated and analyzed the deformation of the underground diaphragm wall of the passage, and compared it with the field measured data. The results show that the maximum horizontal displacement of the underground diaphragm wall is only $0.29 \%$ times of the excavation depth. The bending moment and axial force of the bored cast-inplace pile near the existing overpass are increased. Liu et al. [15] analyzed the field monitoring data of a $38 \mathrm{~m}$ deep foundation pit constructed by a top-down construction method in Shanghai, including the horizontal displacement of the diaphragm wall and the variation of differential settlement of intermediate piles with the progress of construction. The results showed that the maximum horizontal displacement of the diaphragm wall was within the range of $0.2 \% \sim 0.3 \%$ times the excavation depth, and the maximum differential settlement of intermediate piles was less than $1 /$ 500 of the column spacing, all of that meet the deformation control requirements.

With the rapid development of urban rail transit construction, deep foundation pit engineering, to a certain extent, meets the needs of urban construction and development. Still, the surrounding environment of the foundation pit is more complex, the geological conditions are worse, and the research on the construction of foundation pits in underlying strata is less; these factors bring great challenges to the safety of foundation pit construction. In this context, based on the deep foundation pit engineering of Jiangbei working shaft of S2 line of Wenzhou City railway, using the three-dimensional finite element numerical simulation method, aiming at the underground continuous wall support, the soft soil layer of underlying inclined rock surface, and the top-down construction technology, this article makes a comprehensive study on the internal force and deformation effect of deep foundation pit suspended foot diaphragm wall construction. Through the comparative analysis of the numerical simulation results and the field measured data, the construction and support scheme of the diaphragm wall suitable for relying on the project is determined to provide a guarantee for the safety of construction.

\section{Project Overview}

The project on which this article relies is the foundation pit project of the exit shaft of the S2 shield tunnel of Wenzhou City railway in Zhejiang Province, China. The length of the foundation pit is $43 \mathrm{~m}$, the width is $21.9 \mathrm{~m}$ or $27.6 \mathrm{~m}$, and the excavation depth is $51.63 \mathrm{~m}$. The foundation pit is located in the deep muddy soil layer in the Oujiang shoal area. The upper part is about $46 \mathrm{~m}$ of muddy soil and clay layer. There is a deep riprap layer in the middle and a weakly weathered tuff layer in the lower part. The rock surface is horizontally extraverted, and the geological conditions are complex (as shown in Figure 1).

The foundation pit is protected by a diaphragm wall, the thickness of the diaphragm wall is $1.5 \mathrm{~m}$, the width of the standard section is generally $5.5 \mathrm{~m}$, the length of the local special-shaped diaphragm wall is adjusted properly, and the reinforced concrete ring frame beam and each floor plate are 


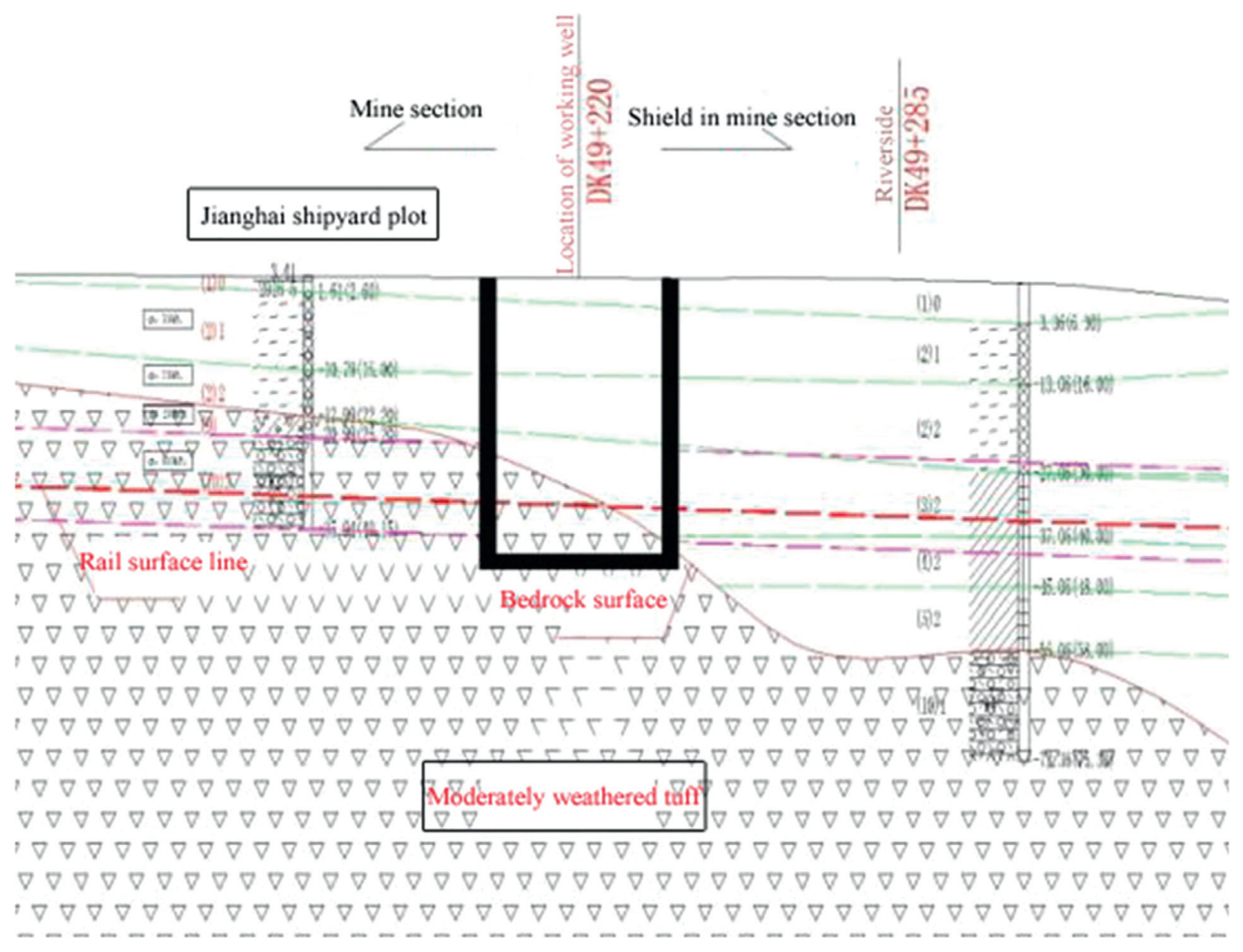

FIGURE 1: Geological profile of Jiangbei working well.

used as the support (as shown in Figure 2). Due to the complex geological conditions, the reverse construction method is adopted in the foundation pit construction. Therefore, how to carry out diaphragm wall construction and foundation pit excavation and support under complex geological conditions and effectively control foundation pit deformation to ensure construction safety is a construction difficulty of the project and also the research focus of this article.

According to the field investigation data, the existing construction equipment and the results of expert discussion, it is proposed to use the suspended foot diaphragm wall for the construction of the foundation pit diaphragm wall, but the specific depth into the rock remains to be determined. In this article, the numerical simulation method will be used to simulate the construction of the suspended footed diaphragm wall so as to determine the depth of the suspended footed diaphragm wall into the rock $(1 \mathrm{~m}, 2 \mathrm{~m}$, and $4 \mathrm{~m})$ and the locking reinforcement scheme of the suspended footed diaphragm wall so as to provide a reference for the smooth progress of the project.

\section{Simulation Scheme Design}

Midas GTS NX is selected as the numerical simulation software in this article because its simulation results are very similar to the measured data (this is because Midas GTS NX can truly simulate the actual construction process according to the setting process of the on-site retaining structure and soil excavation), the constitutive model is rich, and the simulation results have high accuracy in the simulation of foundation pit, slope, tunnel, and other practical projects.

\subsection{Establishment of Numerical Model}

3.1.1. Model Size. According to the actual size of the foundation pit, the calculation model diagram is established (as shown in Figure 3): the length of the foundation pit relying on the project is $43 \mathrm{~m}$, the left width is $21.9 \mathrm{~m}$, the right width is $27.6 \mathrm{~m}$, and the excavation depth is $51.63 \mathrm{~m}$. According to the previous modeling experience, the size of the foundation pit model can generally be 3-5 times the excavation depth of the foundation pit [10]. Finally, the overall size of the foundation pit model is determined as $287 \mathrm{~m}$ long, $227.6 \mathrm{~m}$ wide, and $100 \mathrm{~m}$ high.

3.1.2. Formation Treatment Method. According to the detailed investigation report of the Oujiang North portal tunnel, the soil layer is fine. Through sorting and merging the soil materials with similar properties, the soil materials are divided into five different layers, and the modified Mohr-Coulomb constitutive model is adopted. The material parameters of each layer are shown in Table 1. (Note: the parameters that cannot be provided in the geological survey report are calculated by the empirical method. The other two stiffness properties can be selected according to the compression modulus of a certain ratio. Generally, the secant 


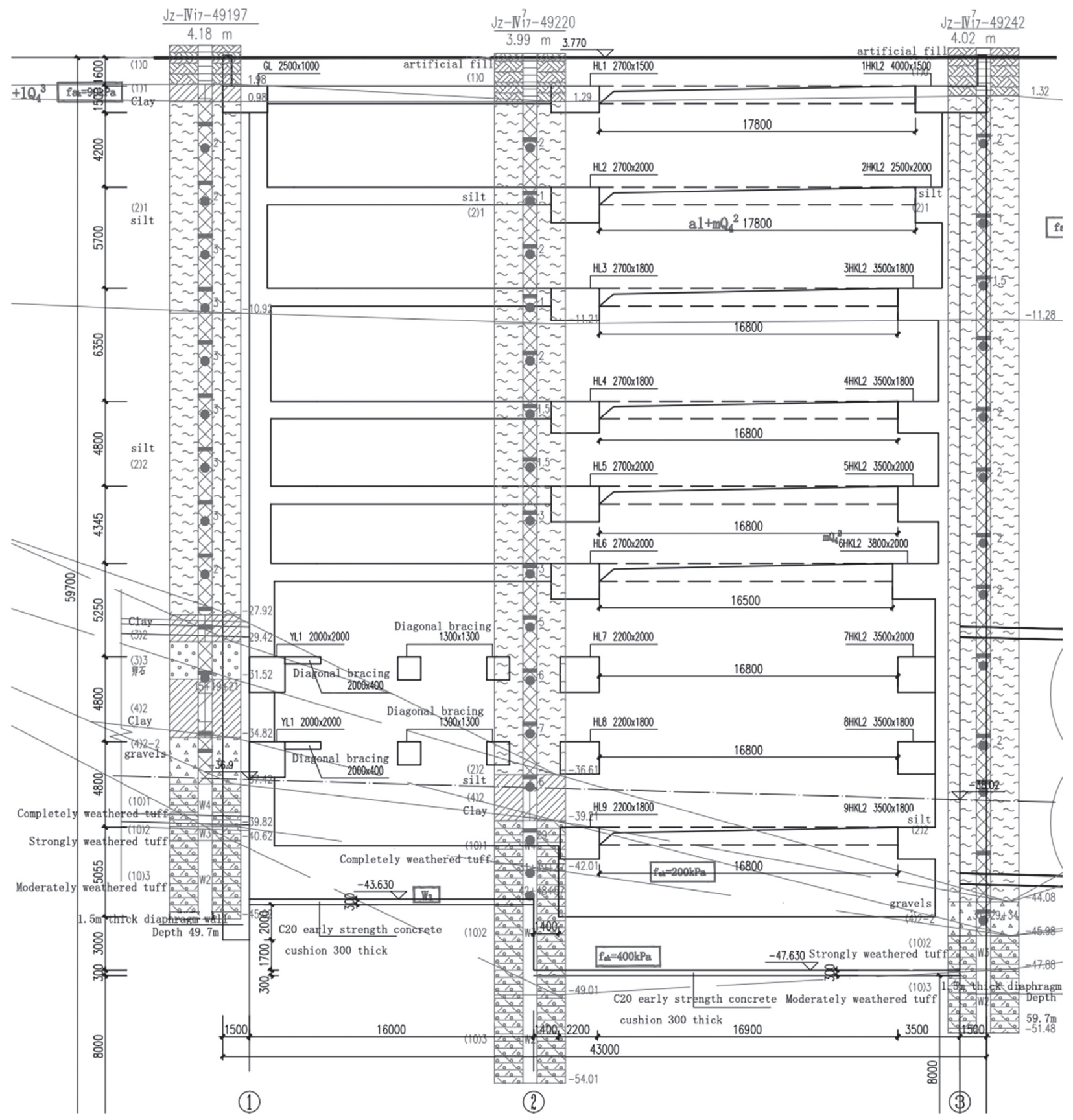

Figure 2: Section diagram of foundation pit supporting structure.

modulus is equal to the tangent modulus and three times the compression modulus.)

3.1.3. Treatment Method of Inclined Strata. According to the geological survey data, the inclined rock surface is diagonally inclined, and the slope of the rock surface is not uniform. It is difficult to model and simulate according to the actual trend, and there are too many irregular grid cells, leading to poor grid quality. When running on a low configuration computer, the calculation process is very slow. In order to meet the needs of simulation calculation, according to the rock surface depth around the foundation pit determined by the investigation, after determining the depth of moderately weathered rock at the interface between the rock surface and the foundation pit, the rock surface trend inside the foundation pit is determined by the slope average method, and the rock surface trend outside the foundation pit is extended according to the slope inside the foundation pit to form the internal rock surface trend of the model. The size of the completed model is shown in Figure 1.

3.2. Selection of Structural Elements and Material Parameters. The supporting structure of the deep foundation pit of the Beikou well is mainly the diaphragm wall, supporting plate, 


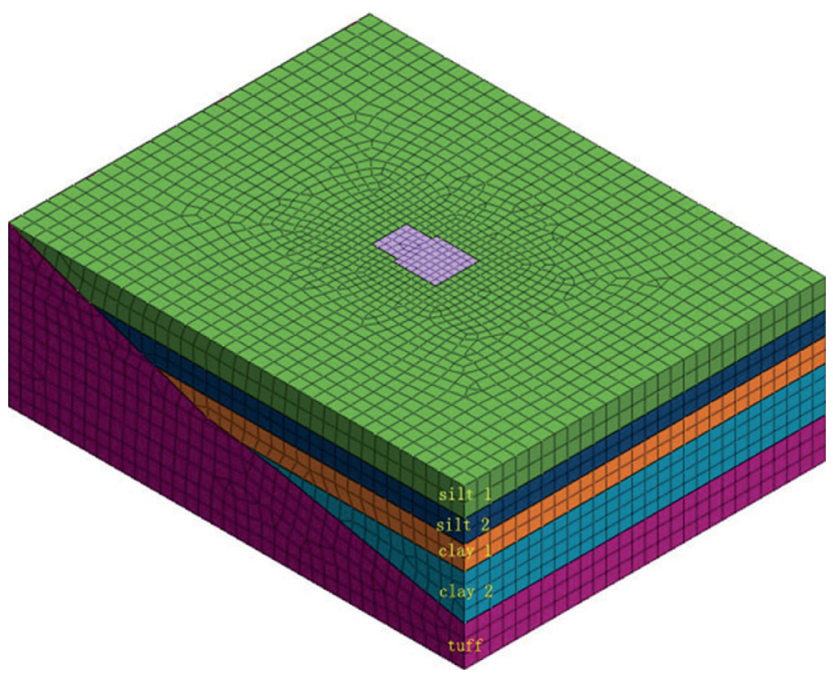

FIgURE 3: Overall calculation model of foundation pit.

TABLE 1: Material parameters of soil layer.

\begin{tabular}{lccccccc}
\hline Number & Layer & Layer thickness $(\mathrm{m})$ & Compression modulus $(\mathrm{MPa})$ & Poisson's ratio & $\begin{array}{c}\text { Unit weight } \\
\left(\mathrm{kN} / \mathrm{m}^{3}\right)\end{array}$ & $\begin{array}{c}\text { Cohesion }(\mathrm{kPa}) \\
\text { Internal friction } \\
\text { angle }\left(^{\circ}\right)\end{array}$ \\
\hline (1) & Silt 1 & 18 & 1.97 & 0.30 & 18 & 6.05 & 2.93 \\
(2) & Silt 2 & 14 & 2.09 & 0.30 & 15 & 6.38 & 3.11 \\
(3) & Clay 1 & 14.8 & 2.98 & 0.40 & 20 & 10.23 & 3.10 \\
(4) & Clay 2 & 3.18 & 3.80 & 0.35 & 18 & 12.45 & 7.58 \\
(5) & Tuff & 1.65 & 500.00 & 0.30 & 23 & 20.00 \\
\hline
\end{tabular}

and reinforced concrete ring frame beam (as shown in Figure 2). The elastic constitutive model is selected for all supporting structures, in which the diaphragm wall and each floor structure adopt a two-dimensional plate element, which is extracted from the three-dimensional solid element. The reinforced concrete ring frame beam is mainly flexural, and its length is larger than the cross-sectional area, so a onedimensional beam element is adopted, which is extracted from the three-dimensional solid element. The material parameters of the supporting structure are shown in Table 2.

3.3. Boundary Conditions and Mesh Generation. In the length direction ( $x$-direction) of the model, the displacement of the $X$-axis is limited, that is, $u=0, V \neq 0, w \neq 0$. In the width direction ( $Y$-direction), the displacement of the $Y$-axis is limited, that is, $u \neq 0, v=0, w \neq 0$. In the height direction ( $z$-direction), the upper boundary of the model is free, i.e., unrestricted, and the lower boundary of the model is fully constrained, i.e., $u=0, v=0, w=0$ ( $U$ is displacement in $X$ direction, $V$ is displacement in $Y$-direction, and $W$ is displacement in $Z$-direction).

Midas GTS provides two types of mesh generation: tetrahedral mesh and hybrid mesh. In this model, the hybrid grid is used. The mixed mesh is mainly hexahedron, with pentahedron and tetrahedron as the transition mesh. Compared with tetrahedral mesh, the hybrid mesh has better stability and higher accuracy. In addition, the number of meshes generated by hybrid mesh is far less than that generated by tetrahedron under the same cell size, which greatly improves the calculation speed. Therefore, when the size of a large engineering model is larger, the hybrid mesh is usually used.

3.4. Determination of Simulated Construction Process. The deep foundation pit is constructed by the top-down method. According to the design and construction technology of the foundation pit, the foundation pit excavation is simulated according to the actual technology. The foundation pit excavation is divided into 12 steps, and the specific construction process is shown in Table 3 .

3.5. Determination of Simulation Conditions. According to the needs of the project, the following two working conditions are determined for the study: (1) suspended foot diaphragm wall; (2) suspended foot to connect the wall, adding anchor lock foot. The construction process of condition (1) is shown in Table 3 above. The first 11 steps of condition (2) are the same as those of condition (1). The 12th step is the tenth excavation to $-51.630 \mathrm{~m}$, and the anchor rod and bottom plate are activated. According to the needs of simulation, the horizontal displacement, bending moment deformation, and surrounding ground settlement of the diaphragm wall are selected as the construction effect indexes.

3.6. Simulation Assumptions. In this article, the outlet well foundation pit is selected, and the calculation model is established considering the surrounding soil. According to 
TABLE 2: Material parameters of supporting structure.

\begin{tabular}{|c|c|c|c|c|c|c|}
\hline Structure name & $\begin{array}{c}\text { Element } \\
\text { type }\end{array}$ & $\begin{array}{c}\text { Constitutive } \\
\text { model }\end{array}$ & $\begin{array}{l}\text { Modulus of elasticity } \\
\left(\mathrm{kN} / \mathrm{m}^{2}\right)\end{array}$ & $\begin{array}{l}\text { Poisson's } \\
\text { ratio }\end{array}$ & $\begin{array}{l}\text { Unit weight }(\mathrm{kN} / \\
\left.\mathrm{m}^{3}\right)\end{array}$ & $\begin{array}{l}\text { Thickness/diameter } \\
(\mathrm{m})\end{array}$ \\
\hline Diaphragm wall & Plate & Elastic & 32500000 & 0.2 & 24.5 & 1.5 \\
\hline Ring frame beam & Beam & Elastic & 32500000 & 0.2 & 24.5 & $3.5 \times 1.8$ \\
\hline $\begin{array}{l}\text { Top plate/middle } \\
\text { plate }\end{array}$ & Plate & Elastic & 32500000 & 0.2 & 24.5 & 0.4 \\
\hline Floor & Plate & Elastic & 32500000 & 0.2 & 24.5 & 3 \\
\hline
\end{tabular}

TABLE 3: Details of construction procedures.

\begin{tabular}{|c|c|}
\hline $\begin{array}{l}\text { Process } \\
\text { number }\end{array}$ & Process node \\
\hline 1 & The original stratum is established, and the initial stress is analyzed by applying boundary constraint and self-weight load \\
\hline 2 & Activate diaphragm wall and clear displacement \\
\hline 3 & The first excavation to $-2.000 \mathrm{~m}$, the first ring frame beam and roof was activated \\
\hline 4 & $\begin{array}{c}\text { The second excavation was to }-7.700 \mathrm{~m} \text {, and the second ring frame beam and the middle slab of the negative first floor } \\
\text { were activated }\end{array}$ \\
\hline 5 & After the third excavation to $-13.400 \mathrm{~m}$, the third ring frame beam and the middle slab of the second floor were activated \\
\hline 6 & The fourth excavation to $-19.750 \mathrm{~m}$, the fourth ring frame beam and the negative third-floor slab were activated \\
\hline 7 & The fifth excavation to $-24.550 \mathrm{~m}$, the fifth ring frame beam and the negative fourth-floor slab were activated \\
\hline 8 & The sixth excavation was to $-28.895 \mathrm{~m}$, and the sixth ring frame beam and the middle slab of the fifth floor were activated \\
\hline 9 & $\begin{array}{c}\text { The seventh excavation was carried out to }-34.145 \mathrm{~m} \text {, and the seventh ring frame beam and the middle slab of the sixth } \\
\text { floor were activated }\end{array}$ \\
\hline 10 & $\begin{array}{l}\text { The eighth excavation to }-38.945 \mathrm{~m} \text {, the eighth ring frame beam and the negative seventh-floor middle plate were } \\
\text { activated }\end{array}$ \\
\hline 11 & $\begin{array}{c}\text { The ninth excavation was carried out to }-43.575 \mathrm{~m} \text {, and the ninth ring frame beam and the middle slab of the eighth floor } \\
\text { were activated }\end{array}$ \\
\hline 12 & The tenth excavation to $-51.630 \mathrm{~m}$, the floor was activated \\
\hline
\end{tabular}

the actual stratum situation and the calculation needs of the model, the following assumptions are made: (1) the soil is isotropic and evenly distributed; (2) the influence of the surrounding environment induced by diaphragm wall construction is not considered; (3) the influence of soil drainage consolidation and groundwater seepage is not considered.

\section{Simulation Study on Construction Effect of Top-Down Construction Method for Foundation Pit with Suspended Foot Diaphragm Wall}

In the original design scheme of Jiangbei working shaft foundation pit, the height of the diaphragm wall is $59.8 \mathrm{~m}$, the thickness is $1.5 \mathrm{~m}$, and the bottom of the diaphragm wall is at the same elevation. However, in the construction process, due to the high strength of moderately weathered rock, the construction speed of existing wall forming equipment is too slow to meet the requirements of the construction period, and the cost is too high. Through the discussion of experts, it is proposed to change the insertion mode of the in situ diaphragm wall into the design scheme of the suspended foot diaphragm wall, which is $2 \mathrm{~m}$ into the rock. The left wall (West wall) of the suspended foot diaphragm wall is $45.82 \mathrm{~m}$ long, and the right wall (east wall) is $51.98 \mathrm{~m}$ long (as shown in Figure 4). It can be seen from Table 3 that there are many excavation conditions, so the 1 st,

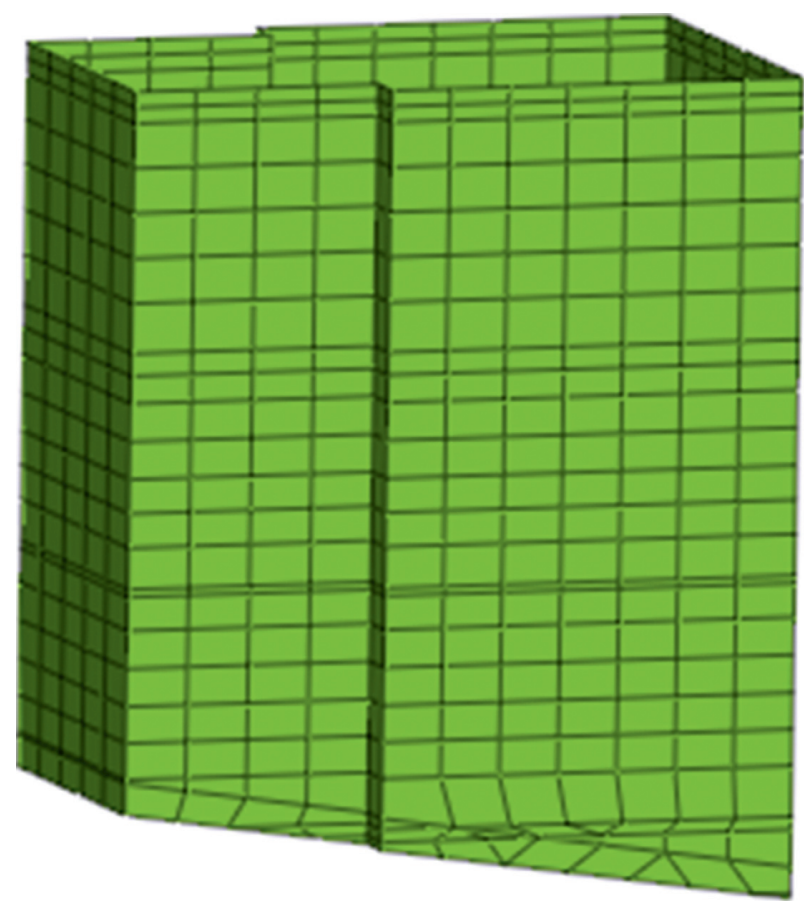

FIgURE 4: Schematic diagram of the ground connection wall the depth into rock is $2 \mathrm{~m}$.

3 rd, 5th, 7th, and 10th excavations (corresponding to process No. 3rd, 7th, 9th, and 12th in Table 3) are selected to study and analyze the foundation pit construction effect. 
4.1. The Horizontal Displacement Analysis. The horizontal displacement contour plot of the diaphragm wall under five excavation conditions is shown in Figure 5. In the contour plot, the one on the left is the west wall, and the one on the right is the east wall (the same below).

After sorting and analyzing the data in Figure 5, we can get the relationship curve between the depth and displacement of the footed diaphragm wall (as shown in Figure 6) and combine the maximum horizontal displacement and depth data of the footed diaphragm wall into a table (as shown in Table 4).

It can be seen from Figure 6 and Table 4 that the horizontal displacement of the foot diaphragm wall is small in the first excavation. With the excavation of the foundation pit, the pouring of the middle plate structure, the support of the ring frame beam, and the horizontal displacement curve of the foot diaphragm wall are in the shape of "small at both ends, large in the middle." The maximum horizontal displacement of the diaphragm wall gradually moves down with the increase of excavation depth and finally locates above the excavation surface. The maximum horizontal displacement is about $7 / 10 \sim 3 / 4$ times the final excavation depth of the foundation pit.

In addition, when the diaphragm wall is a suspender and the underlying strata are less embedded, the displacement and deformation of the end and bottom of the suspender diaphragm wall are larger. The maximum horizontal displacement of the east wall is larger than that of the west wall, which is due to the existence of inclined rock surface. The displacement and deformation law of the east and west walls is asymmetric, and the maximum horizontal displacement position gradually moves down with the excavation condition.

4.2. Bending Moment Analysis. The bending moment contour plot of the diaphragm wall under five excavation conditions is shown in Figure 7.

By sorting and analyzing the data in Figure 7, the relationship curve between depth and bending moment of the hanging foot ground connecting wall can be obtained, as shown in Figure 8, and the maximum bending moment and depth data of the hanging foot ground connecting wall can be summarized into a table, as shown in Table 5 .

It can be seen from Figure 7 and Table 5 that the bending moment of the diaphragm wall is small in the first excavation, and there is a reverse bending point. With the progress of excavation, the bending moment of the diaphragm wall increases gradually and then decreases slightly in the final excavation stage. In each excavation stage, the maximum positive bending moment of the diaphragm wall is larger than the maximum negative bending moment. The maximum positive bending moment of the diaphragm wall is about 7/10 3/4 times the final excavation depth of the foundation pit, and the maximum negative bending moment is about $4 / 5 \sim 19 / 20$ times the final excavation depth of the foundation pit.

In addition, the maximum positive bending moment is larger than the maximum negative bending moment in each excavation stage. The position of the maximum positive bending moment of the east and west walls first moves down and then rises and then remains unchanged after the original position. The position of the maximum negative bending moment does not change with the change of the excavation stage (except for the tenth excavation of the east wall). Due to the existence of inclined strata, the maximum bending moment of the east wall is larger than that of the west wall in each excavation stage (except for the negative bending moment of the tenth excavation), and the deformation law of the east wall and the west wall is basically the same but asymmetric.

4.3. Analysis of Surface Subsidence. The contour plot of soil surface settlement under five excavation conditions is shown in Figure 9.

By sorting and analyzing the data in Figure 9, the relationship curve between surface settlement and distance from foundation pit can be obtained, as shown in Figure 10, and the data of maximum surface settlement position can be summarized into a table, as shown in Table 6.

Through comprehensive analysis of Figures 9 and 10 and Table 6, the following conclusions can be obtained:

(1) During the first excavation, the surface settlement of the soil is very small. The maximum surface settlement of the soil on the east and west sides is about $0.5 \mathrm{~mm}$. The maximum settlement is located $10 \mathrm{~m}$ away from the edge of the foundation pit, and the settlement beyond $20 \mathrm{~m}$ is almost zero.

(2) During the third excavation, the soil surface settlement increased, and the maximum settlement was about $4.0 \sim 4.5 \mathrm{~mm}$. The soil surface settlement position changed, all located $15 \mathrm{~m}$ away from the edge of the foundation pit, and the soil surface settlement outside $60 \mathrm{~m}$ was small.

(3) During the fifth excavation, the surface settlement of the soil continued to increase, and the maximum surface settlement was about $11.5 \mathrm{~mm}$, an increase of about 1.8 times that of the third excavation, which was consistent with the sudden increase of the horizontal displacement and a bending moment of the diaphragm wall during the fifth excavation. Due to the deformation law of the diaphragm wall, the surface also had a large settlement. The maximum surface settlement positions of the soil on the east and west sides changed and were located away from the foundation at $20 \mathrm{~m}$ around the pit; the surface settlement of soil mass beyond $80 \mathrm{~m}$ is about $0.8 \sim 0.9 \mathrm{~mm}$.

(4) During the seventh excavation, the soil surface settlement continues to increase with a small increase. The maximum surface settlement of the soil is about $14.0 \sim 15.0 \mathrm{~mm}$, the maximum surface settlement position remains unchanged $(20 \mathrm{~m}$ in the west and $20 \mathrm{~m}$ in the east), and the surface settlement outside $85 \mathrm{~m}$ is about $0.8 \sim 0.9 \mathrm{~mm}$. 


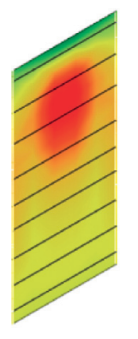

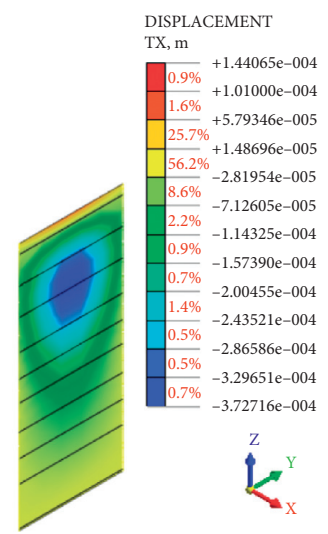

(a)

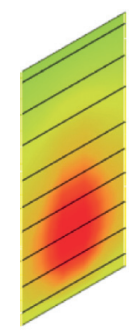

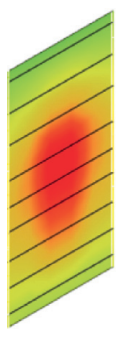

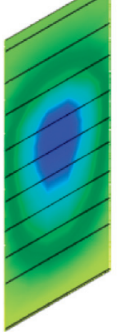

(b)

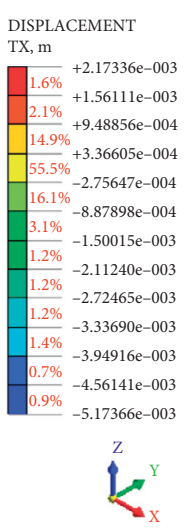

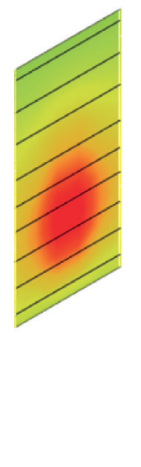

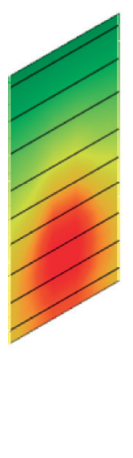

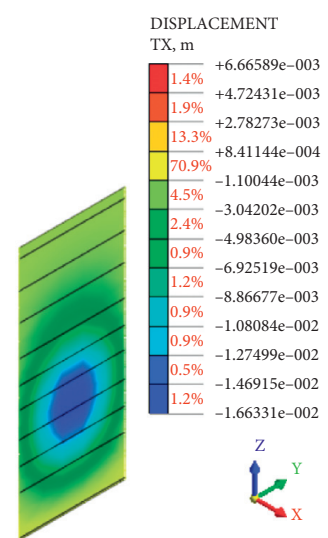

(c)
DISPLACEMENT

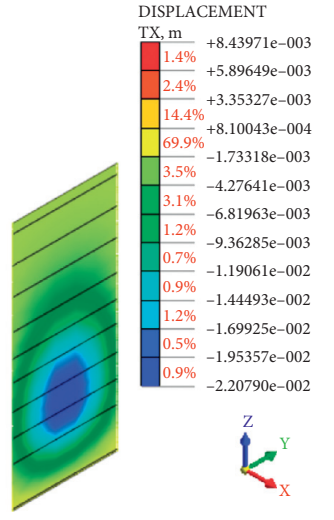

(d)

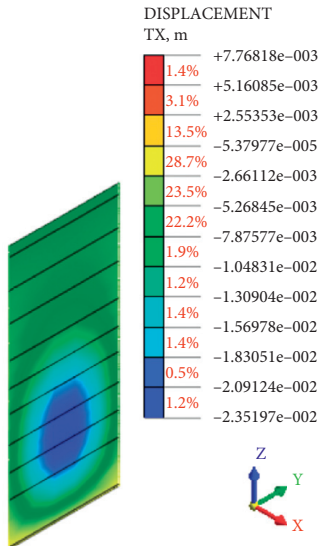

(e)

Figure 5: Horizontal displacement contour plot of suspended diaphragm wall under five excavation conditions. (a) First excavation, (b) third excavation, (c) the fifth excavation, (d) the seventh excavation, and (e) the tenth excavation.

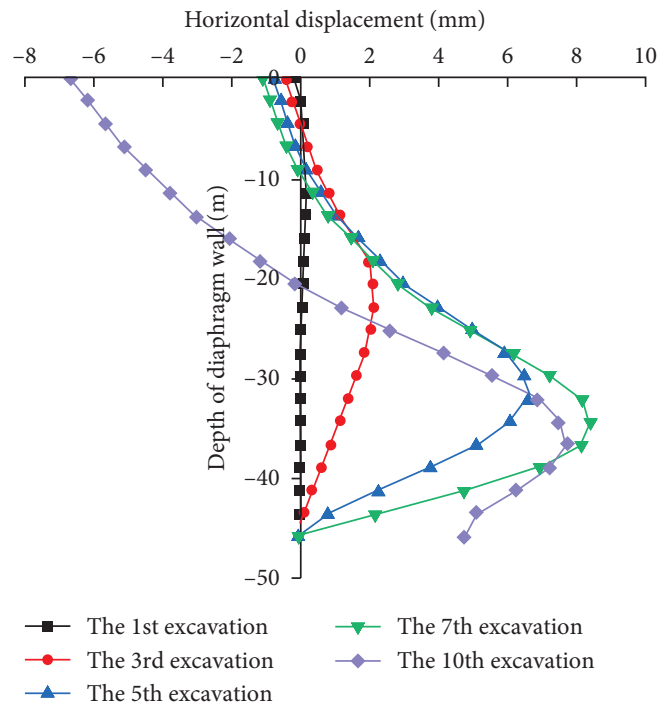

(a)

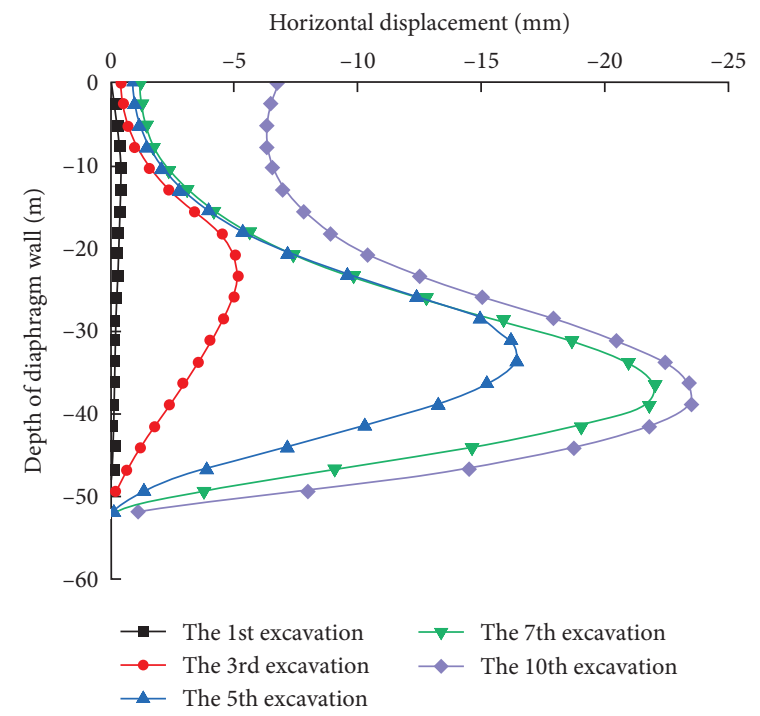

(b)

FIgURE 6: The relation curve of depth horizontal displacement of the foot diaphragm wall. (a) The west wall and (b) the east wall. 
TABLe 4: Summary of the corresponding depth of the maximum horizontal displacement of the suspended foot connected wall.

\begin{tabular}{|c|c|c|c|c|}
\hline \multirow[b]{2}{*}{ Working procedure } & \multicolumn{2}{|c|}{$\begin{array}{l}\text { Suspended foot diaphragm wall (west, the length is } \\
\qquad 45.82 \mathrm{~m} \text { ) }\end{array}$} & \multicolumn{2}{|c|}{$\begin{array}{l}\text { Suspended foot diaphragm wall (east, the length is } \\
\qquad 51.98 \mathrm{~m} \text { ) }\end{array}$} \\
\hline & $\begin{array}{l}\text { Maximum horizontal } \\
\text { displacement }(\mathrm{mm})\end{array}$ & $\begin{array}{l}\text { The depth of } \\
\text { the diaphragm wall } \\
\text { (m) }\end{array}$ & $\begin{array}{l}\text { Maximum } \\
\text { horizontal displacement } \\
(\mathrm{mm})\end{array}$ & $\begin{array}{l}\text { The depth of the diaphragm } \\
\text { wall }(\mathrm{m})\end{array}$ \\
\hline $\begin{array}{l}\text { The first excavation } \\
(-2.000 \mathrm{~m})\end{array}$ & 0.141 & -11.46 & -0.371 & -13.00 \\
\hline $\begin{array}{l}\text { The third excavation } \\
(-13.400 \mathrm{~m})\end{array}$ & 2.146 & -22.91 & -5.170 & -23.39 \\
\hline $\begin{array}{l}\text { The fifth excavation } \\
(-24.550 \mathrm{~m})\end{array}$ & 6.613 & -32.07 & -16.490 & -33.79 \\
\hline $\begin{array}{l}\text { The seventh excavation } \\
(-34.145 \mathrm{~m})\end{array}$ & 8.418 & -34.37 & -22.006 & -36.39 \\
\hline $\begin{array}{l}\text { The tenth excavation } \\
(-51.630 \mathrm{~m})\end{array}$ & 7.738 & -36.66 & -23.497 & -38.99 \\
\hline
\end{tabular}

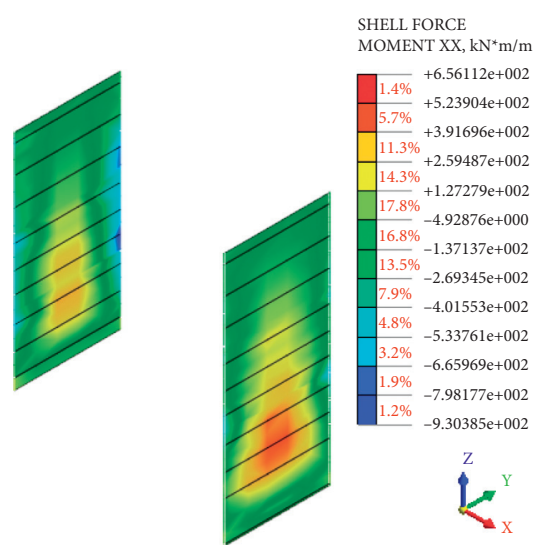

(a)

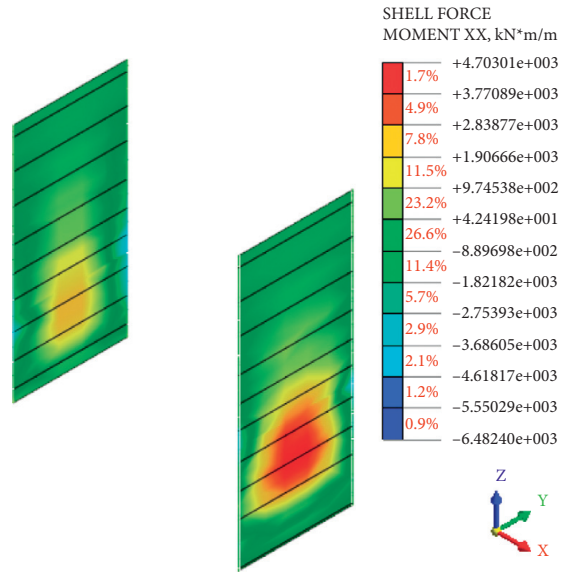

(d)

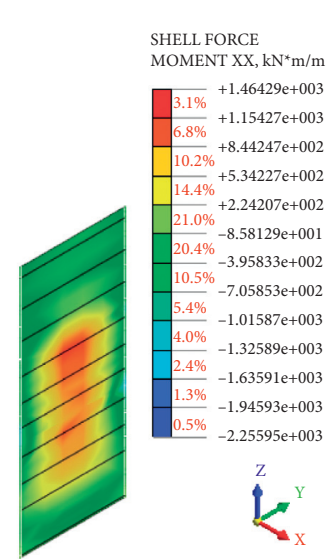

(b)

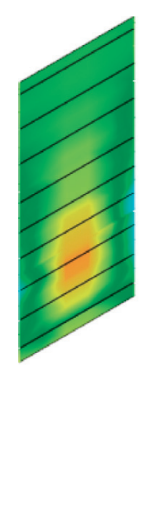

SHELL FORCE MOMENT XX, $\mathrm{kN} * \mathrm{~m} / \mathrm{m}$
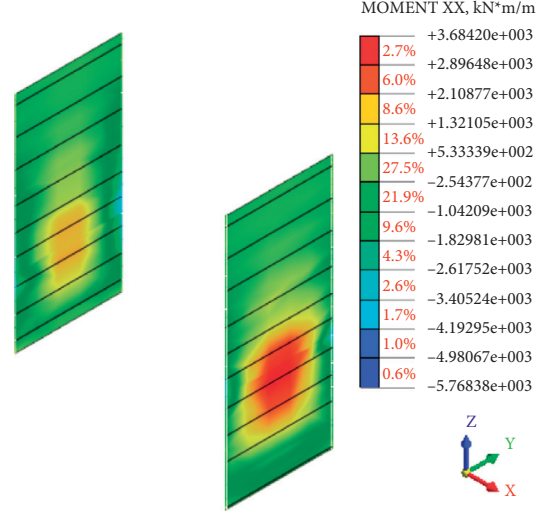

(c)

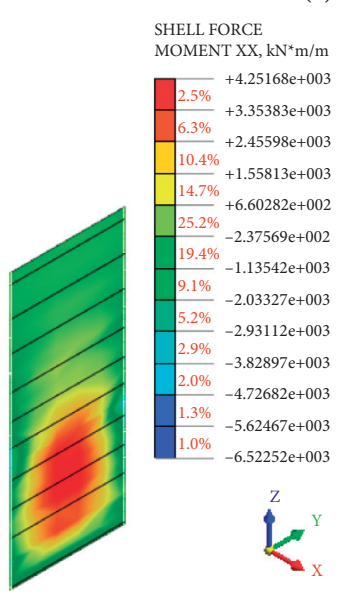

(e)

FIgURE 7: The bending moment contour plot of suspended diaphragm wall under five excavation step conditions. (a) The first excavation step, (b) the third excavation step, (c) the fifth excavation step, (d) the seventh excavation step, and (e) the tenth excavation step.

(5) After the tenth excavation, the surface settlement of soil continued to increase, the maximum surface settlement of soil was about $18.4 \mathrm{~mm}$, and the location of the maximum surface settlement changed (the west side is $15 \mathrm{~m}$ and the east side is $15 \mathrm{~m})$. The maximum surface settlement is about $0.036 \%$ of the excavation depth of the foundation pit of $51.630 \mathrm{~m}$, about $78 \%$ of the maximum horizontal displacement of the hanging foot ground connecting wall. The maximum surface settlement is located $15 \mathrm{~m}$ away from the edge of the foundation pit, about 0.3 times the excavation depth of the foundation pit of $51.630 \mathrm{~m}$. 


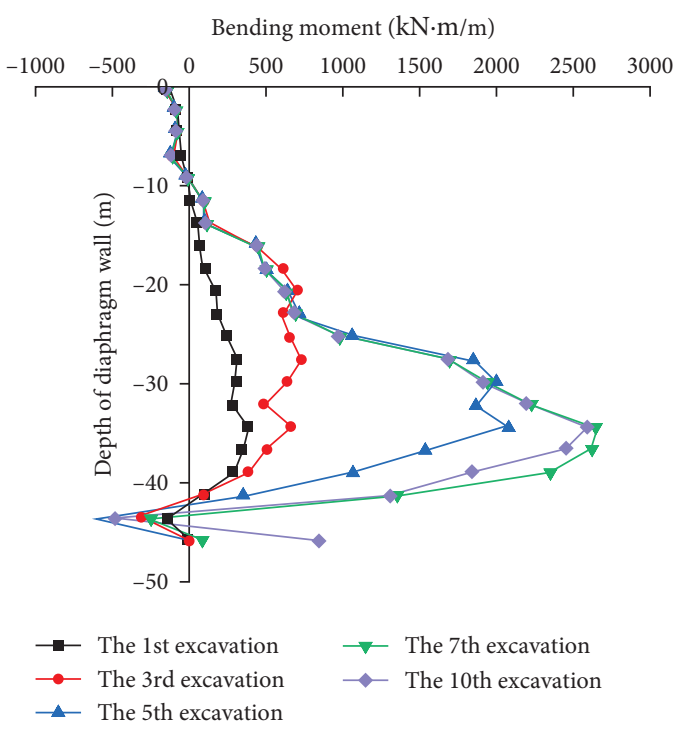

(a)

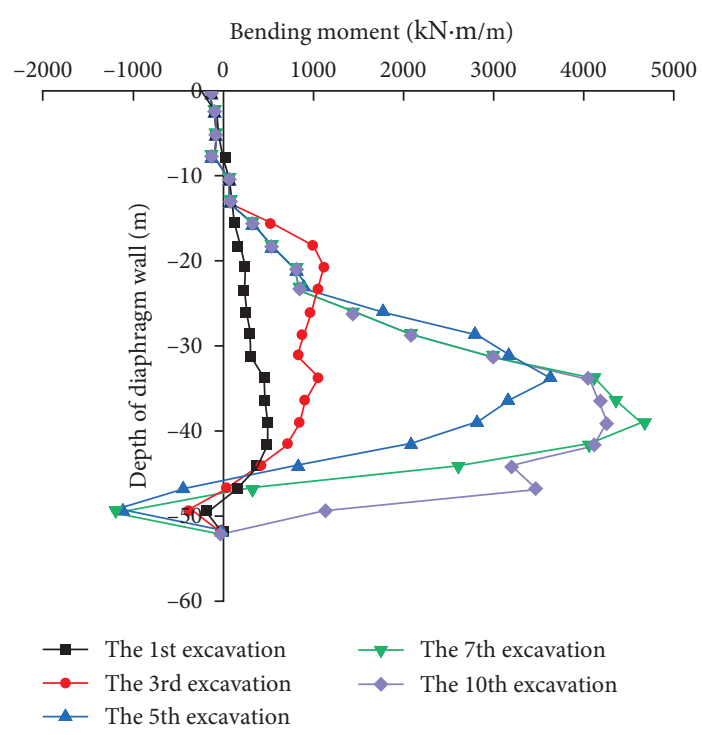

(b)

Figure 8: The relation curve between depth and horizontal displacement of the foot diaphragm wall. (a) The west wall and (b) the east wall.

TABLE 5: Summary of the corresponding depth of the maximum bending moment of the suspended foot connecting wall.

\begin{tabular}{|c|c|c|c|c|}
\hline \multirow{2}{*}{ Working procedure } & \multicolumn{2}{|c|}{$\begin{array}{l}\text { Suspended foot diaphragm wall (west, the length is } \\
\qquad 45.82 \mathrm{~m} \text { ) }\end{array}$} & \multicolumn{2}{|c|}{$\begin{array}{l}\text { Suspended foot diaphragm wall (east, the length is } \\
\qquad 51.98 \mathrm{~m} \text { ) }\end{array}$} \\
\hline & $\begin{array}{l}\text { Maximum bending } \\
\text { moment }(\mathrm{kN} \cdot \mathrm{m} / \mathrm{m})\end{array}$ & $\begin{array}{l}\text { The depth of the } \\
\text { diaphragm wall }(\mathrm{m})\end{array}$ & $\begin{array}{l}\text { Maximum bending } \\
\text { moment }(\mathrm{kN} \cdot \mathrm{m} / \mathrm{m})\end{array}$ & $\begin{array}{l}\text { The depth of the } \\
\text { diaphragm wall }(\mathrm{m})\end{array}$ \\
\hline $\begin{array}{l}\text { The first excavation } \\
(-2.000 \mathrm{~m})\end{array}$ & $383.553 /-154.641$ & $-34.37 /-43.53$ & $495.496 /-183.378$ & $-38.99 /-49.38$ \\
\hline $\begin{array}{l}\text { The third excavation } \\
(-13.400 \mathrm{~m})\end{array}$ & $732.862 /-311.066$ & $-27.49 /-43.53$ & $1127.781 /-404.225$ & $-20.79 /-49.38$ \\
\hline $\begin{array}{l}\text { The fifth excavation } \\
(-24.550 \mathrm{~m})\end{array}$ & $2080.852 /-600.905$ & $-34.37 /-43.53$ & $3621.628 /-1118.857$ & $-33.79 /-49.38$ \\
\hline $\begin{array}{l}\text { The seventh excavation } \\
(-34.145 \mathrm{~m})\end{array}$ & $2654.072 /-250.395$ & $-34.37 /-43.53$ & $4654.927 /-1193.643$ & $-38.99 /-49.38$ \\
\hline $\begin{array}{l}\text { The tenth excavation } \\
(-51.630 \mathrm{~m})\end{array}$ & $2596.608 /-469.726$ & $-34.37 /-43.53$ & $4251.651 /-42.949$ & $-38.99 /-51.98$ \\
\hline
\end{tabular}

Remarks

Among the maximum bending moments in the table, the maximum positive bending moment value is before "/" and the maximum negative bending moment value is after "/," respectively, corresponding to the depth of the diaphragm wall.

(6) It can be seen from the above construction stages that the soil surface settlement curve in each construction stage first increases and then decreases with the distance from the edge of the foundation pit and finally tends to be stable, showing a "groove shape." According to the curve, the law of surface settlement and deformation on the east and west sides is basically the same. The maximum settlement position of the surface on the east and west sides is the same, which is finally located at 0.3 times the final excavation depth of the foundation pit, and the main influence area is about 1.5 times the final excavation depth of the foundation pit. determine the relationship between the foot and the depth of rock in the foot diaphragm wall, the numerical simulation models of the foot diaphragm wall with the depth of $1 \mathrm{~m}$ and $4 \mathrm{~m}$ are established, respectively. The other setting conditions are completely consistent with the depth of $2 \mathrm{~m}$. The maximum horizontal displacement, maximum bending moment, and maximum surface settlement of the foot diaphragm wall with different depths of rock are obtained and summarized into a table (as shown in Table 7).

The following can be seen from Table 7:

(1) The results show that the horizontal displacement, bending moment, and surface settlement of the diaphragm wall decrease with the increase of the depth of the diaphragm wall.

(2) When the depth of the suspended footed diaphragm wall increases from $1 \mathrm{~m}$ to $2 \mathrm{~m}$, the horizontal 


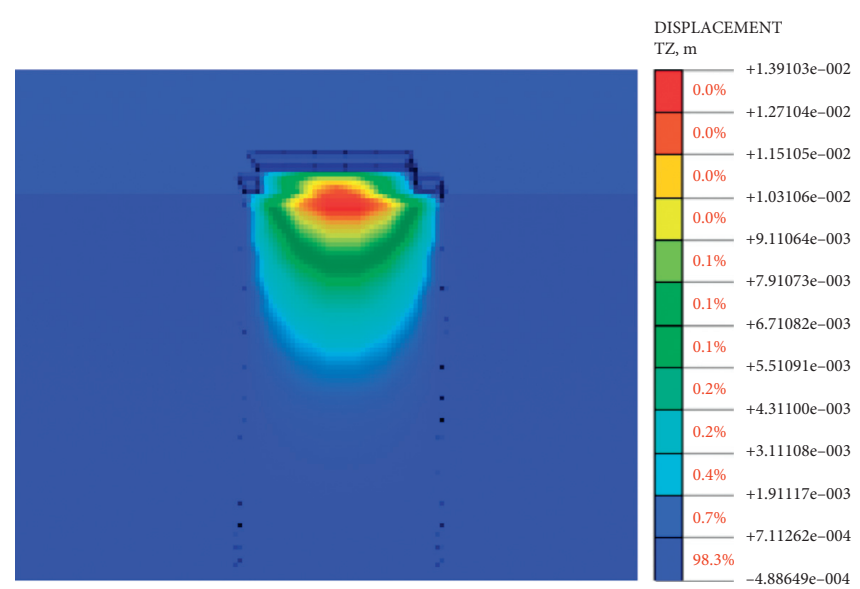

(a)

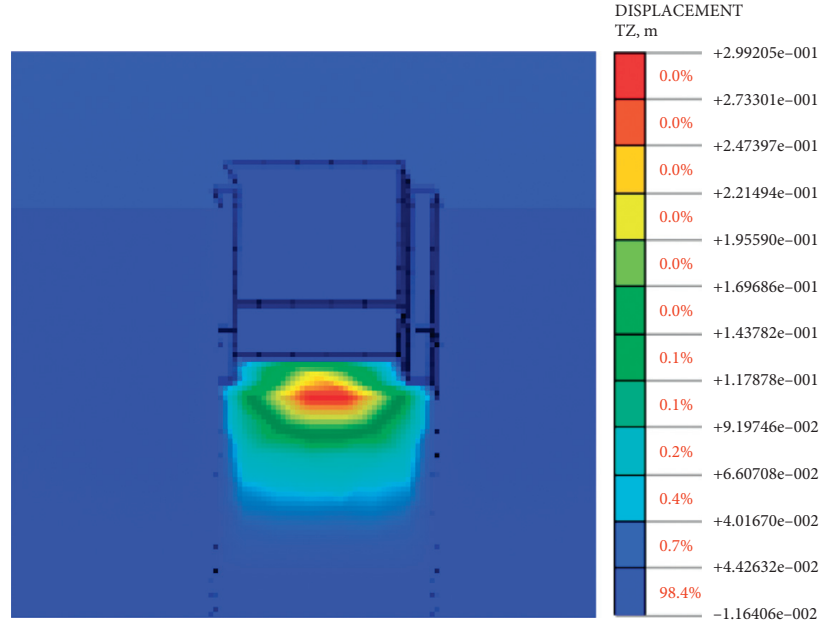

(c)

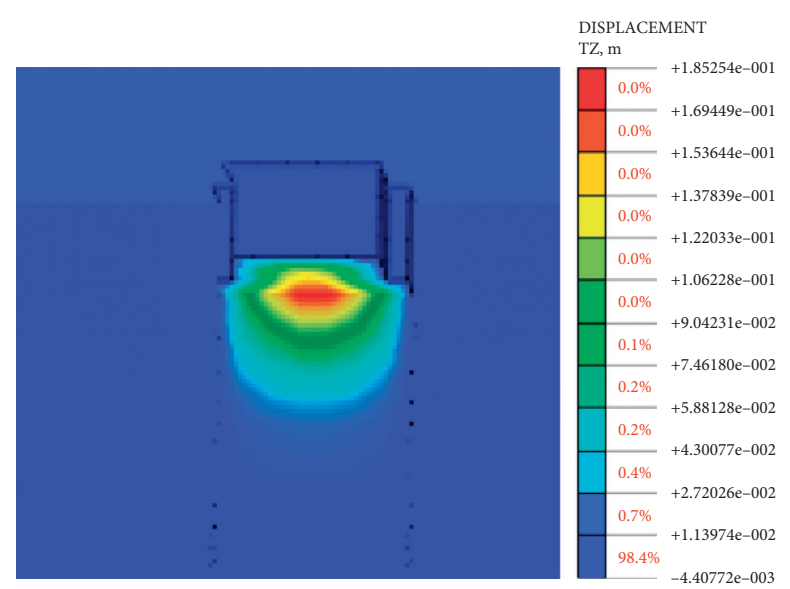

(b)

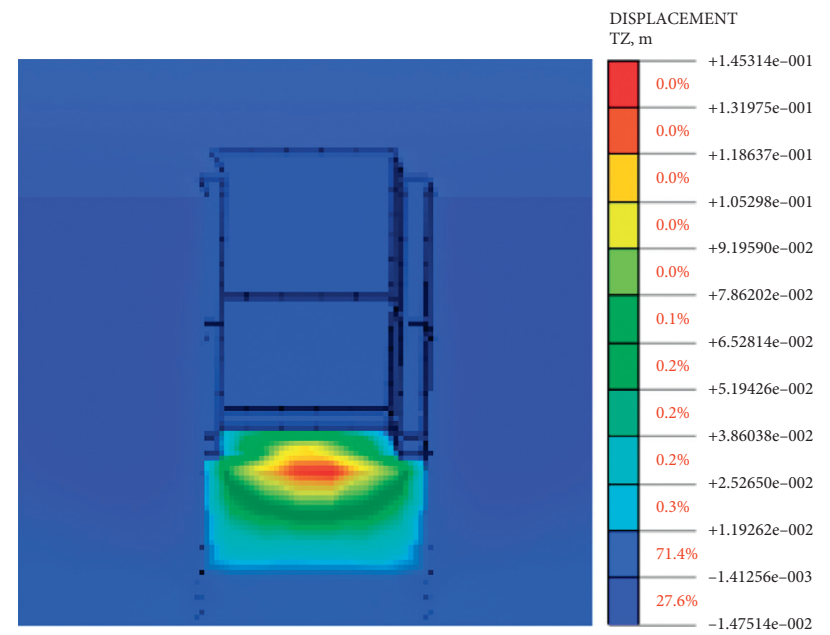

(d)

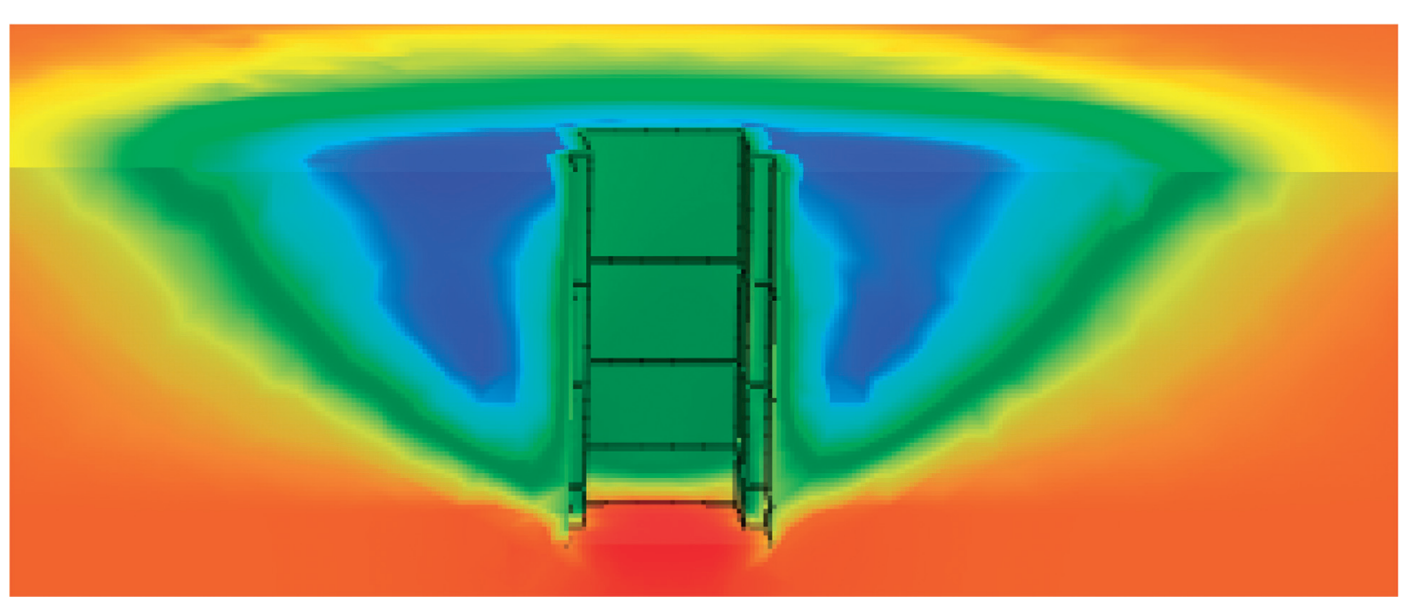

DISPLACEMENT TZ, $\mathrm{m}$

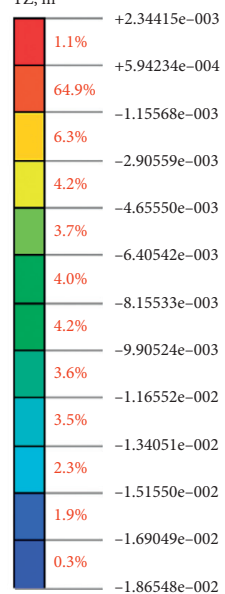

(e)

FIGURE 9: The contour plot of surface settlement under five excavation step conditions. (a) The first excavation step, (b) the third excavation step, (c) the fifth excavation step, (d) the seventh excavation step, and (e) the tenth excavation step.

displacement of the suspended footed diaphragm wall decreases by $0.916 \mathrm{~mm}$ and $0.975 \mathrm{~mm}$ for every $1 \mathrm{~m}$ increase. When the rock depth increases from $2 \mathrm{~m}$ to $4 \mathrm{~m}$, the horizontal displacement and surface settlement decrease by $0.470 \mathrm{~mm}$ and $0.578 \mathrm{~mm}$ for each $1 \mathrm{~m}$ increase. When the rock depth increases from $1 \mathrm{~m}$ to $4 \mathrm{~m}$, the bending moment of the diaphragm wall decreases gradually. 


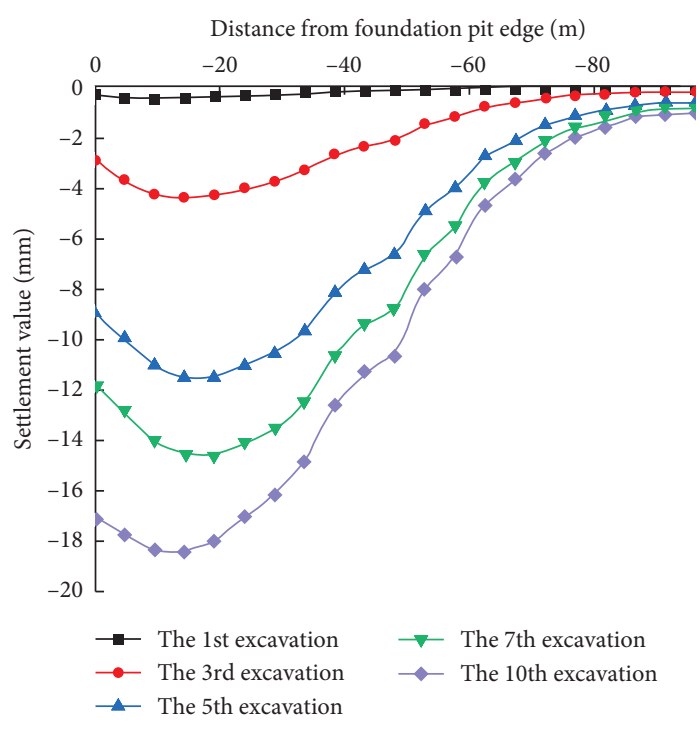

(a)

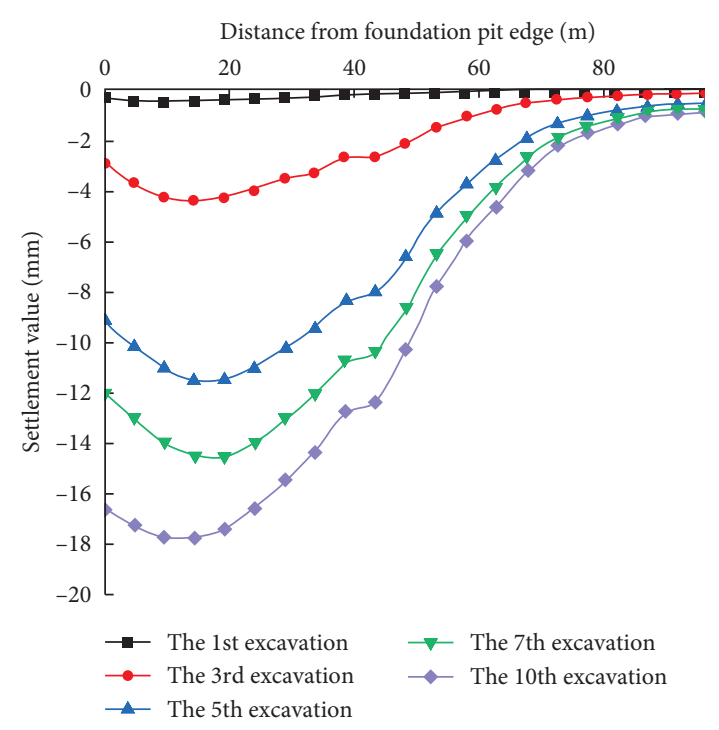

(b)

FIgURE 10: The curve of surface subsidence. (a) The west wall and (b) the east wall.

TABLE 6: Summary of the corresponding position of the maximum subsidence of the surface.

\begin{tabular}{|c|c|c|c|c|}
\hline \multirow[b]{2}{*}{ Working procedure } & \multicolumn{2}{|c|}{ External surface of foundation pit (west) } & \multicolumn{2}{|c|}{ External surface of foundation pit (east) } \\
\hline & $\begin{array}{l}\text { Maximum settlement } \\
(\mathrm{mm})\end{array}$ & $\begin{array}{l}\text { Distance from foundation pit } \\
\text { edge }(\mathrm{m})\end{array}$ & $\begin{array}{l}\text { Maximum settlement } \\
(\mathrm{mm})\end{array}$ & $\begin{array}{l}\text { Distance from foundation pit } \\
\text { edge }(\mathrm{m})\end{array}$ \\
\hline $\begin{array}{l}\text { The first excavation } \\
(-2.000 \mathrm{~m})\end{array}$ & -0.459 & 10.00 & -0.476 & 10.00 \\
\hline $\begin{array}{l}\text { The third excavation } \\
(-13.400 \mathrm{~m})\end{array}$ & -4.385 & 15.00 & -4.393 & 15.00 \\
\hline $\begin{array}{l}\text { The fifth excavation } \\
(-24.550 \mathrm{~m})\end{array}$ & -11.511 & 20.00 & -11.511 & 20.00 \\
\hline $\begin{array}{l}\text { The seventh excavation } \\
(-34.145 \mathrm{~m})\end{array}$ & -14.621 & 20.00 & -14.526 & 20.00 \\
\hline $\begin{array}{l}\text { The tenth excavation } \\
(-51.630 \mathrm{~m})\end{array}$ & -18.419 & 15.00 & -17.778 & 15.00 \\
\hline
\end{tabular}

(3) Through the analysis of the data, it can be seen that the increase of the depth of the foot diaphragm wall into the rock can effectively reduce the deformation of the foundation pit. However, when the depth of the rock increases to a certain extent, the effect of continuing to increase the depth of the rock is no longer obvious, so on the premise of the safety and stability of the foundation pit and reducing the cost, this article selects the foot diaphragm wall foundation pit with the depth of $2 \mathrm{~m}$ into the rock to continue to optimize.

\section{Simulation Study on Locking Reinforcement Scheme of Suspended Diaphragm Wall}

In practical engineering, when the footwall is excavated below the footwall, the footwall may be separated from the rock, resulting in large displacement, affecting the stability of the foundation pit, so it is necessary to lock the footwall. According to the engineering experience, the reinforcement measures of the locking anchor are often adopted. Therefore, this article optimizes the reinforcement based on the depth $(2 \mathrm{~m})$ of the suspended foot diaphragm wall into the rock.

5.1. Design Parameters of Foot Bolt. According to the bolt design specification, the horizontal spacing of bolts should be greater than $1.5 \mathrm{~m}$, and the mesh size of the foundation pit in the model is 4 , which is greater than 1.5. The angle of the inclined anchor should be from 15 to 25 , so the angle of the anchor should be 20, and the thickness of the overlying soil should be more than $4 \mathrm{~m}$. The project is covered with soft clay about $46 \mathrm{~m}$, and the bolt is a full grouting bolt with a length of $10 \mathrm{~m}$. The anchor rod is arranged $1 \mathrm{~m}$ below the soil rock interface. The elastic constitutive model is selected for the bolt. Because the bolt ignores the bending deformation and mainly bears the axial force, the one-dimensional embedded truss element is used to directly divide the onedimensional element, and the material parameters of the bolt are shown in Table 8. Other conditions are completely 
TABLE 7: Summary of maximum deformation of foundation pit with different rock entry depths.

\begin{tabular}{|c|c|c|c|}
\hline Rock penetration depth of foot diaphragm wall $(\mathrm{m})$ & 1 & 2 & 4 \\
\hline Horizontal displacement of foot diaphragm wall $(\mathrm{mm})$ & -24.413 & -23.497 & -22.557 \\
\hline Bending moment of foot diaphragm wall $(\mathrm{kN} \bullet \mathrm{m} / \mathrm{m})$ & 4697.035 & 4654.927 & 4285.135 \\
\hline Surface settlement $(\mathrm{mm})$ & -19.394 & -18.419 & -17.263 \\
\hline
\end{tabular}

TABLE 8: Anchor material parameters.

\begin{tabular}{lcccccc}
\hline Structure name & Element type & Constitutive model & $\begin{array}{c}\text { Modulus of elasticity } \\
\left(\mathrm{kN} / \mathrm{m}^{2}\right)\end{array}$ & Poisson's ratio & $\begin{array}{c}\text { Unit weight } \\
\left(\mathrm{kN} / \mathrm{m}^{3}\right)\end{array}$ & $\begin{array}{c}\text { Thickness/diameter }(\mathrm{m}) \\
\text { Anchor }\end{array}$ \\
\hline
\end{tabular}

consistent with those of the suspended diaphragm wall (the model is shown in Figure 11).

\subsection{Simulation Study on Construction Effect of Bolt Foot} Locking and Foot Suspended Diaphragm Wall. It can be seen from Table 3 that due to many excavation conditions, the $1 \mathrm{st}, 3 \mathrm{rd}, 5 \mathrm{th}, 7 \mathrm{th}$, and 10 th excavations (corresponding to the $3 \mathrm{rd}, 7 \mathrm{th}$, 9th, and 12 th processes in Table 3 ) are selected to study and analyze the construction effect of anchor bolt foot locking and foot suspended diaphragm wall foundation pit.

Here, it should be emphasized that since the horizontal displacement, bending moment, and surface settlement cloud pictures obtained by the simulation of the construction effect of the anchor bolt locking foot and the suspended foot diaphragm wall are similar to those of the suspended foot diaphragm wall, the simulation cloud pictures corresponding to the above three construction effect indexes are no longer displayed here.

5.2.1. Horizontal Displacement Analysis. By sorting and analyzing the data in the horizontal displacement cloud diagram obtained from the simulation, the relationship curve between the depth and horizontal displacement of the anchor bolt foot hanger diaphragm wall can be obtained, as shown in Figure 12, and the maximum horizontal displacement and depth data of the anchor bolt foot hanger diaphragm wall can be summarized into a table, as shown in Table 9.

It can be seen from Figure 12 and Table 9 that the horizontal displacement of the anchor bolt locking foot suspended diaphragm wall is small in the first excavation. With the excavation of the foundation pit, the horizontal displacement curve of the suspended foot diaphragm wall is in the shape of "small at both ends and large in the middle." When the footed diaphragm wall is excavated to the bottom and separated from the rock stratum, adding bolt locking feet can effectively restrain the displacement and deformation of the end and bottom of the footed diaphragm wall, so as to reduce the overall horizontal displacement and deformation of the footed diaphragm wall. The maximum horizontal displacement of the east

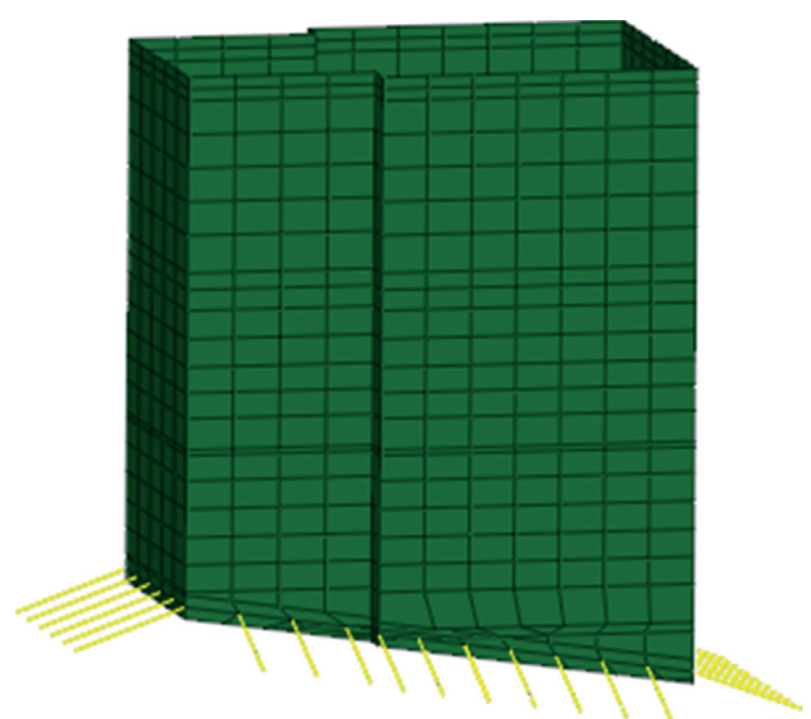

FIGURE 11: Schematic diagram of anchor lock foot suspended foot connecting wall model.

wall is larger than that of the west wall, which is due to the existence of inclined rock surface. The displacement and deformation law of the east and west walls is asymmetric, and the maximum horizontal displacement position gradually moves down with the excavation condition. The maximum horizontal displacement of the east wall is larger than that of the west wall, which is due to the existence of inclined rock surface. The displacement and deformation law of the east and west walls is asymmetric, and the maximum horizontal displacement position gradually moves down with the excavation condition. The maximum horizontal displacement of diaphragm wall moves downward with the increase of excavation depth, and finally above the excavation surface. The maximum horizontal displacement is about $7 / 10 \sim 3 / 4$ times of the final excavation depth of foundation pit. Compared with the cantilever diaphragm wall, the increase of displacement is more stable. The bolt can effectively restrain the increase of displacement at the end and bottom of the diaphragm wall, and the restraint effect of the end displacement is more obvious. 


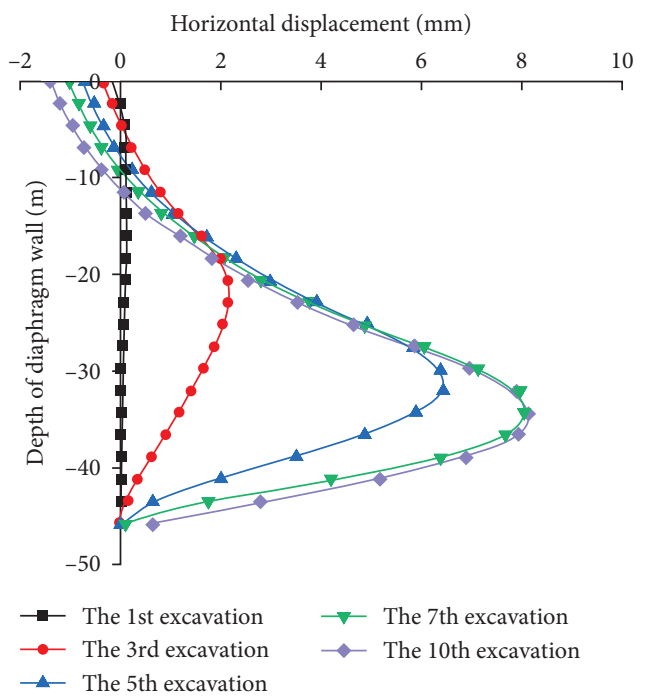

(a)

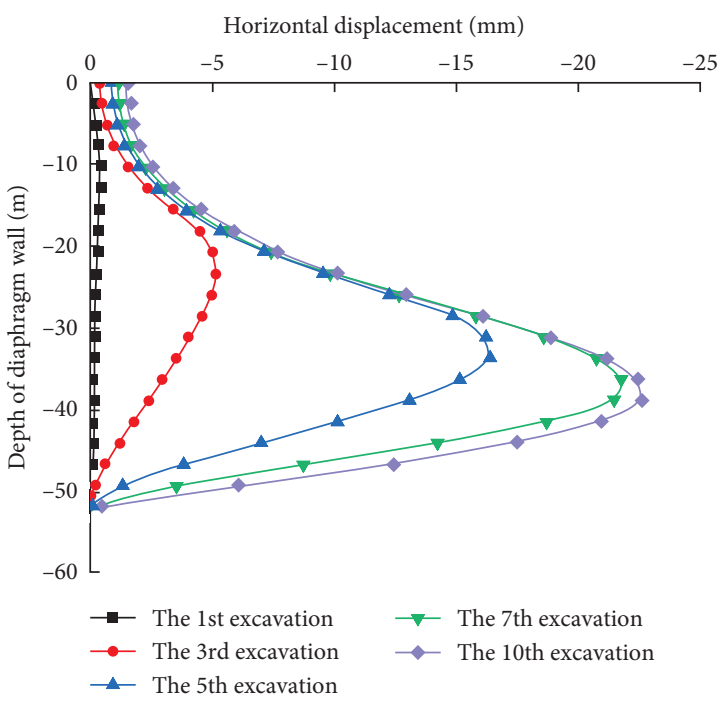

(b)

Figure 12: The horizontal displacement curve of anchor bolt locking foot suspended foot diaphragm wall. (a) The west wall and (b) the east wall.

TABle 9: Summary of the corresponding depth of the maximum horizontal displacement of the anchor lock foot connecting wall.

\begin{tabular}{|c|c|c|c|c|}
\hline \multirow[b]{2}{*}{ Working procedure } & \multicolumn{2}{|c|}{$\begin{array}{l}\text { Suspended foot diaphragm wall (west, the } \\
\text { length is } 45.82 \mathrm{~m} \text { ) }\end{array}$} & \multicolumn{2}{|c|}{ Suspended foot diaphragm wall (east, the length is $51.98 \mathrm{~m}$ ) } \\
\hline & $\begin{array}{c}\text { Maximum } \\
\text { horizontal } \\
\text { displacement }(\mathrm{mm})\end{array}$ & $\begin{array}{c}\text { The depth } \\
\text { of the diaphragm } \\
\text { wall }(\mathrm{m})\end{array}$ & $\begin{array}{l}\text { Maximum horizontal } \\
\text { displacement }(\mathrm{mm})\end{array}$ & $\begin{array}{l}\text { The depth of the } \\
\text { diaphragm wall }(\mathrm{m})\end{array}$ \\
\hline $\begin{array}{l}\text { The first excavation } \\
(-2.000 \mathrm{~m})\end{array}$ & 0.142 & -11.46 & -0.371 & -13.00 \\
\hline $\begin{array}{l}\text { The third excavation } \\
(-13.400 \mathrm{~m})\end{array}$ & 2.151 & -22.91 & -5.158 & -23.39 \\
\hline $\begin{array}{l}\text { The fifth excavation } \\
(-24.550 \mathrm{~m})\end{array}$ & 6.463 & -32.07 & -16.400 & -33.79 \\
\hline $\begin{array}{l}\text { The seventh excavation } \\
(-34.145 \mathrm{~m})\end{array}$ & 8.099 & -34.37 & -21.823 & -36.39 \\
\hline
\end{tabular}

5.2.2. The Bending Moment Analysis. By sorting and analyzing the data in the bending moment cloud diagram obtained from the simulation, the relationship curve between the depth and bending moment of the anchor bolt foot hanger diaphragm wall can be obtained, as shown in Figure 13, and the maximum bending moment and depth data of the anchor bolt foot hanger diaphragm wall can be summarized into a table, as shown in Table 10.

It can be seen from Figure 13 and Table 10 that the bending moment of the first excavation of the diaphragm wall with bolt locking and foot suspended is small, and there is a reverse bending point. With the progress of excavation, the bending moment of the diaphragm wall gradually increases, and then slightly decreases compared with the previous excavation stage. In each excavation stage, the maximum positive bending moment of the diaphragm wall is larger than the maximum negative bending moment. The maximum positive moment is larger than the maximum negative moment at each excavation stage. The location of the maximum negative moment of the east and west walls does not change with the excavation stage. Due to the existence of inclined strata, the maximum positive bending moment of the east wall is larger than that of the west wall in each excavation stage, and the deformation law of the east wall and the west wall is basically the same, but asymmetric. The maximum positive bending moment of diaphragm wall is about $7 / 10 \sim 3 / 4$ times of the final excavation depth of foundation pit, and the maximum negative bending moment is about $4 / 5 \sim 19 / 20$ times of the final excavation depth of foundation pit. Compared with the suspended diaphragm wall, the anchor can effectively control the bending moment deformation of diaphragm wall, especially the bottom bending moment deformation of diaphragm wall.

5.2.3. Analysis of Surface Subsidence. By sorting and analyzing the data in the simulated surface settlement cloud map, the curve of surface settlement distance from the foundation pit edge can be obtained, as shown in Figure 14, and the data of the location of the maximum surface 


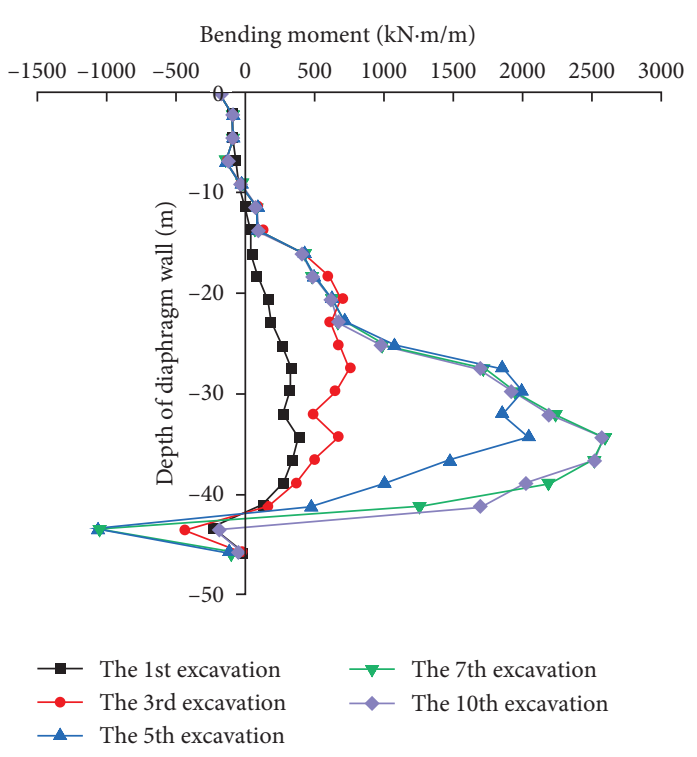

(a)

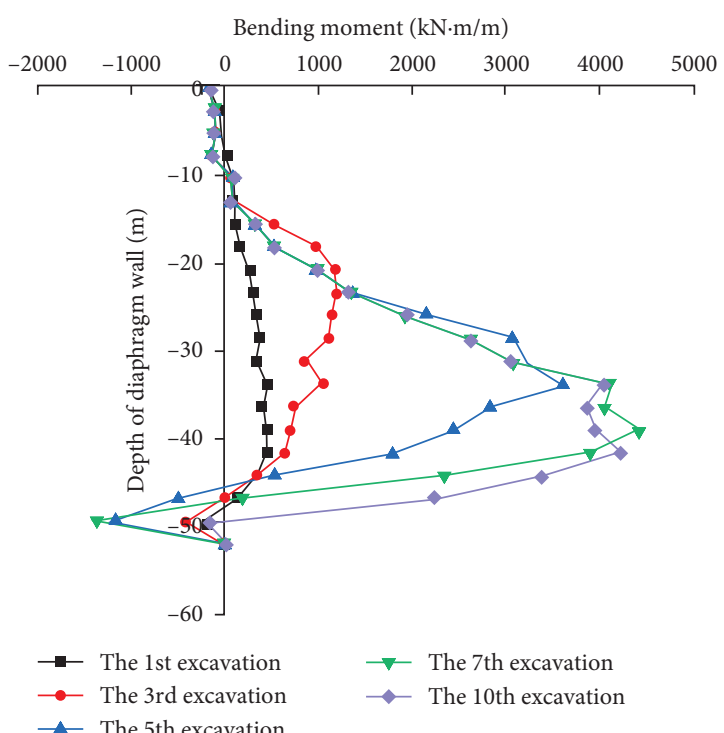

(b)

FIGURE 13: The bending moment curve of anchor bolt locking foot suspended foot diaphragm wall. (a) West wall, (b) east wall.

TABLE 10: Summary of the corresponding depth of the maximum bending moment of the anchor lock foot suspended foot connecting wall.

\begin{tabular}{|c|c|c|c|c|}
\hline \multirow{2}{*}{ Working procedure } & \multicolumn{2}{|c|}{$\begin{array}{l}\text { Suspended foot diaphragm wall (west, the length is } \\
\qquad 45.82 \mathrm{~m} \text { ) }\end{array}$} & \multicolumn{2}{|c|}{$\begin{array}{l}\text { Suspended foot diaphragm wall (east, the length is } \\
\qquad 51.98 \mathrm{~m} \text { ) }\end{array}$} \\
\hline & $\begin{array}{l}\text { Maximum bending } \\
\text { moment }(\mathrm{kN} \cdot \mathrm{m} / \mathrm{m})\end{array}$ & $\begin{array}{c}\text { The depth of } \\
\text { diaphragm wall }(\mathrm{m})\end{array}$ & $\begin{array}{l}\text { Maximum bending } \\
\text { moment }(\mathrm{kN} \cdot \mathrm{m} / \mathrm{m})\end{array}$ & $\begin{array}{c}\text { The depth of } \\
\text { diaphragm wall }(\mathrm{m})\end{array}$ \\
\hline $\begin{array}{l}\text { The first } \\
\text { excavation }(-2.000 \mathrm{~m})\end{array}$ & $333.942 /-230.579$ & $-27.49 /-43.53$ & $460.319 /-184.544$ & $-33.79 /-49.38$ \\
\hline $\begin{array}{l}\text { The third } \\
\text { excavation }(-13.400 \mathrm{~m})\end{array}$ & $751.792 /-436.294$ & $-27.49 /-43.53$ & $1198.865 /-414.313$ & $-23.39 /-49.38$ \\
\hline $\begin{array}{l}\text { The fifth } \\
\text { excavation }(-24.550 \mathrm{~m})\end{array}$ & $2042.740 /-1060.720$ & $-34.37 /-43.53$ & $3626.023 /-1160.760$ & $-33.79 /-49.38$ \\
\hline $\begin{array}{l}\text { The seventh } \\
\text { excavation }(-34.145 \mathrm{~m})\end{array}$ & $2596.272 /-1049.140$ & $-34.37 /-43.53$ & $4425.413 /-1356.545$ & $-38.99 /-49.38$ \\
\hline $\begin{array}{l}\text { The first } \\
\text { excavation }(-2.000 \mathrm{~m})\end{array}$ & $2576.597 /-191.356$ & $-34.37 /-43.53$ & $4239.727 /-168.822$ & $-41.58 /-49.38$ \\
\hline
\end{tabular}

Remarks

Among the maximum bending moments in the table, the maximum positive bending moment value is before "/", and the maximum negative bending moment value is after "/", respectively corresponding to the depth of diaphragm wall.

settlement can be summarized into a table, as shown in Table 11.

It can be seen from Figure 14 and Table 11 that the settlement of soil surface is small at the first excavation, but it increases gradually with the excavation. In each construction stage, the surface settlement curve of soil increases first, then decreases, and finally tends to be stable with the distance from the foundation pit edge, showing a "groove" curve, and the surface settlement deformation law of the east and west sides is basically the same. The maximum surface settlement is about $0.03 \%$ of the final excavation depth of the foundation pit, about $70 \%$ of the maximum horizontal displacement of the suspended foot diaphragm wall. The maximum surface settlement is located at a distance of $15 \mathrm{~m}$ from the edge of the foundation pit, about 0.3 times of the final excavation depth of the foundation pit, and the main impact area is about 1.5 times of the final excavation depth of the foundation pit. Compared with the suspended foot diaphragm wall, the anchor rod controls the surface settlement to a certain extent.

5.3. Simulation Study on the Influence of Different Anchor Positions of Lock Foot on Foundation Pit. In order to further determine the relationship between the reinforcement effect of anchor foot and anchor position, the model of anchor position at the soil rock interface is established. Other setting conditions are consistent with the standard model. The maximum horizontal displacement, maximum bending moment and maximum surface settlement of foundation pit at different anchor positions are obtained and summarized into a table, as shown in Table 12 . 


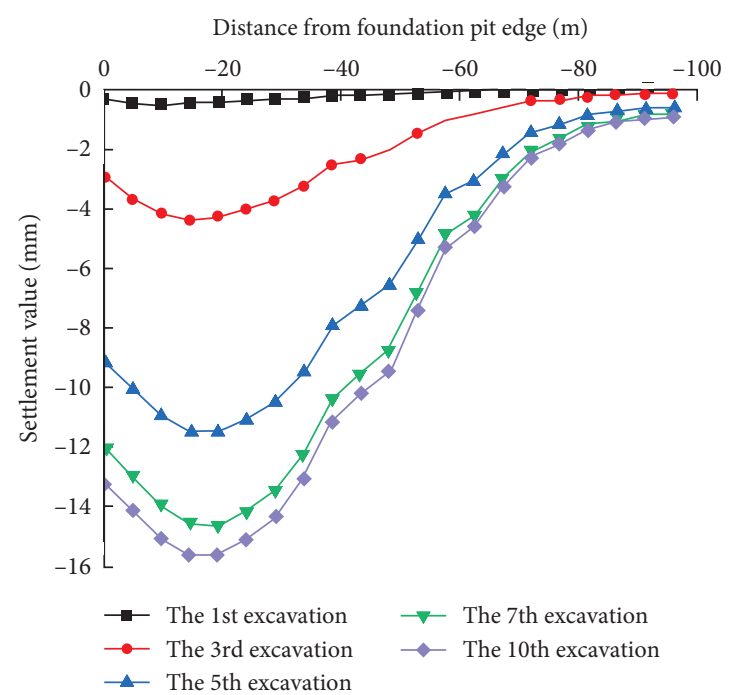

(a)

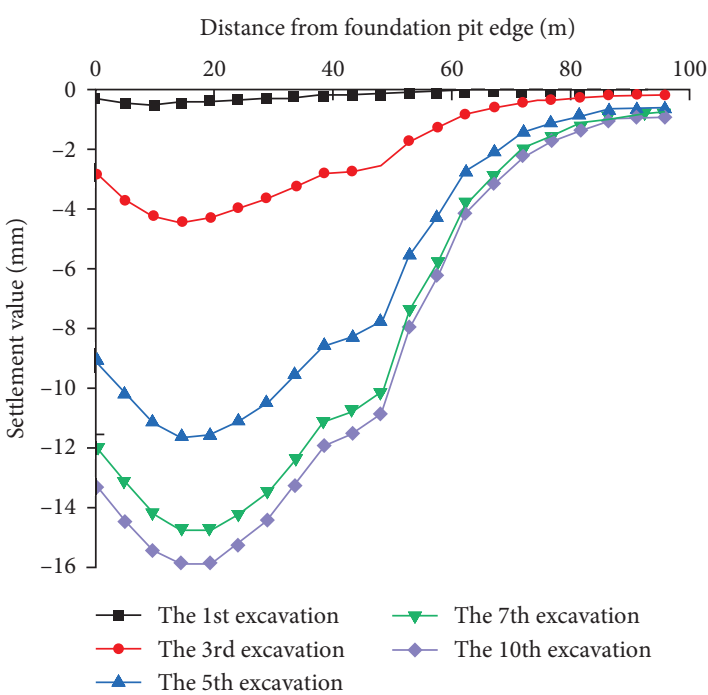

(b)

FIGURE 14: The curve of surface subsidence. (a) West wall, (b) east wall.

TABLE 11: Summary of the corresponding position of the maximum subsidence of the surface.

\begin{tabular}{|c|c|c|c|c|}
\hline \multirow[b]{2}{*}{ Working procedure } & \multicolumn{2}{|c|}{ External surface of foundation pit (west) } & \multicolumn{2}{|c|}{ External surface of foundation pit (east) } \\
\hline & $\begin{array}{l}\text { Maximum settlement } \\
(\mathrm{mm})\end{array}$ & $\begin{array}{l}\text { Distance from foundation pit } \\
\text { edge }(\mathrm{m})\end{array}$ & $\begin{array}{c}\text { Maximum } \\
\text { settlement } \\
(\mathrm{mm})\end{array}$ & $\begin{array}{l}\text { Distance from foundation pit } \\
\text { edge }(\mathrm{m})\end{array}$ \\
\hline The first excavation $(-2.000 \mathrm{~m})$ & -0.467 & 10.00 & -0.482 & 10.00 \\
\hline $\begin{array}{l}\text { The third } \\
\text { excavation }(-13.400 \mathrm{~m})\end{array}$ & -4.380 & 15.00 & -4.369 & 15.00 \\
\hline $\begin{array}{l}\text { The fifth } \\
\text { excavation }(-24.550 \mathrm{~m})\end{array}$ & -11.468 & 20.00 & -11.594 & 15.00 \\
\hline $\begin{array}{l}\text { The seventh } \\
\text { excavation }(-34.145 \mathrm{~m})\end{array}$ & -14.601 & 20.00 & -14.741 & 15.00 \\
\hline The first excavation $(-2.000 \mathrm{~m})$ & -15.600 & 20.00 & -15.913 & 15.00 \\
\hline
\end{tabular}

TABle 12: Summary of maximum deformation of foundation pit with different anchoring positions.

\begin{tabular}{lcc}
\hline Anchor position of lock foot & The interface between soil and rock $1 \mathrm{~m}$ below the interface between soil and rock \\
\hline Horizontal displacement of diaphragm wall $(\mathrm{mm})$ & -23.494 & -22.665 \\
Bending moment value of diaphragm wall $(\mathrm{kN} \bullet \mathrm{m} / \mathrm{m})$ & 4668.444 & 4425.413 \\
Surface settlement $(\mathrm{mm})$ & -18.224 & -15.913 \\
\hline
\end{tabular}

It can be seen from Table 12 that as followings:

(1) The horizontal displacement, bending moment and ground settlement of the diaphragm wall decrease with the downward movement of the anchor position.

(2) Through the analysis of the data, it can be seen that the anchor can effectively reduce the deformation of the foundation pit, but if the anchor position is not set reasonably, it will not only not achieve the goal of effectively reducing the deformation, but also increase the cost. Therefore, on the premise of ensuring the safety and stability of the foundation pit, the anchor position should be selected properly. Therefore, based on the analysis of the simulation results and the reality, this paper selects $1 \mathrm{~m}$ below the interface between soil and rock as the anchorage position.

\section{Comparative Analysis of Simulation Results of Diaphragm Wall Construction Effect under Different Working Conditions}

6.1. Comparative Analysis of Horizontal Displacement of Diaphragm Wall. After sorting and analyzing the data in the horizontal displacement contour plot of diaphragm wall during the 10th excavation (i.e. the foundation pit is excavated to the bottom) under two working conditions, the 
depth-displacement curve of diaphragm wall under two working conditions can be obtained, as shown in Figure 14, and the maximum horizontal displacement and depth data of diaphragm wall under two working conditions can be summarized into a table, as shown in Table 13.

It can be seen from Figure 15 and Table 13 that the 10th excavation entered into moderately weathered rock stratum with high strength. In case 1 , the maximum horizontal displacement of the west wall is $8.256 \mathrm{~mm}$, which is at the depth of $-32.89 \mathrm{~m}$. The maximum horizontal displacement of the east wall is $-22.341 \mathrm{~mm}$, which is located at the depth of $-38.87 \mathrm{M}$. In case 2 , the maximum horizontal displacement of the west wall is $7.738 \mathrm{~mm}$ at the depth of $-36.66 \mathrm{~m}$. The maximum horizontal displacement of the east wall is $-23.497 \mathrm{~mm}$, which is located at the depth of $-38.99 \mathrm{~m}$.

From the comparison of the two working conditions, it can be seen that the maximum horizontal displacement of the west wall is reduced by $0.518 \mathrm{~mm}$, the maximum horizontal displacement of the east wall is increased by $1.156 \mathrm{~mm}$, the horizontal displacement of the end and bottom of the diaphragm wall is increased suddenly, and the stability of the diaphragm wall is poor, which is due to the large horizontal displacement and deformation due to the lack of rock embedment in working condition 2, Therefore, the horizontal displacement of condition 2 is larger than that of condition 1 , and the maximum horizontal displacement of condition 2 moves down.

6.2. The Bending Moment Analysis of Diaphragm Wall. By sorting and analyzing the data in the bending moment contour plot of diaphragm wall during the 10th excavation (i.e. the foundation pit is excavated to the bottom) under two working conditions, the depth bending moment curve of diaphragm wall under two working conditions can be obtained, as shown in Figure 16, and the maximum bending moment and depth data of diaphragm wall under two working conditions can be summarized into a table, as shown in Table 14.

It can be seen from Figure 16 and Table 14 that the tenth excavation entered the moderately weathered rock stratum with high strength on the left and low strength on the right. In case 1 , the maximum positive bending moment of the west wall is $2596.608 \mathrm{kN} \bullet \mathrm{m} / \mathrm{m}$, which is located at the depth of $-34.37 \mathrm{~m}$. The maximum positive bending moment of the east wall is $4251.651 \mathrm{kN} \bullet \mathrm{m} / \mathrm{m}$, which is located at the depth of $-38.99 \mathrm{~m}$. The maximum negative bending moment of the west wall is $-469.726 \mathrm{kN} \cdot \mathrm{m} / \mathrm{m}$, which is located at the depth of $-43.53 \mathrm{~m}$. The maximum negative bending moment of the east wall is $-42.949 \mathrm{kN} \cdot \mathrm{m} / \mathrm{m}$ which is located at the depth of $-51.98 \mathrm{~m}$. In case 2 , the maximum positive bending moment of the west wall is $2576.597 \mathrm{kN} \cdot \mathrm{m} / \mathrm{m}$, which is located at the depth of $-34.37 \mathrm{~m}$; The maximum positive bending moment of the east wall is $4239.727 \mathrm{kN} \cdot \mathrm{m} / \mathrm{m}$, which is located at the depth of $-41.58 \mathrm{~m}$. The maximum negative bending moment of the west wall is $-191.356 \mathrm{kN} \bullet \mathrm{m} / \mathrm{m}$, which is located at the depth of $-43.53 \mathrm{~m}$; The maximum negative bending moment of the east wall is $-168.822 \mathrm{kN} \cdot \mathrm{m} / \mathrm{m}$, which is located at the depth of $-49.38 \mathrm{~m}$.
From the comparison of the two working conditions, it can be seen that the maximum positive bending moment of the east wall and the west wall is reduced, the maximum negative bending moment of the west wall is reduced, and the maximum negative bending moment of the east wall is increased. There is a small negative bending moment at the bottom of the west wall, and the bending moment at the bottom of the east wall is almost zero. This is due to the important constraint of the anchor, which effectively reduces the maximum positive bending moment of the diaphragm wall and the bending moment at the bottom of the diaphragm wall, In case 2 , the location of the maximum positive (negative) bending moment of the west wall remains unchanged, the location of the maximum positive bending moment of the east wall moves down, and the location of the maximum negative bending moment of the east wall moves up. In both cases, the maximum positive bending moment of the east and west walls appears above the excavation face, which indicates that the rock embedment in the diaphragm wall has a great constraint on the bending moment deformation of the diaphragm wall. The maximum positive moment of the two walls is larger than the maximum negative moment. Because of the existence of inclined rock, the maximum bending moment of the east wall is larger than that of the west wall.

6.3. Comparative Analysis of Ground Settlement of Diaphragm Wall. By sorting and analyzing the data in the contour plot of ground settlement of diaphragm wall soil mass during the 10th excavation (i.e. excavation to the bottom) under two working conditions, the curve of ground settlement distance from the edge of foundation pit under two working conditions can be obtained, as shown in Figure 17, and the data of maximum ground settlement position under two working conditions can be summarized into a table, as shown in Table 15 .

It can be seen from Figure 17 and Table 15 that the tenth excavation entered the moderately weathered rock stratum. In case 1, the maximum settlement of the soil surface on the west side of the foundation pit is $-18.419 \mathrm{~mm}$, which is $15 \mathrm{~m}$ away from the side of the foundation pit; The maximum surface settlement of the east side soil is $-17.778 \mathrm{~mm}$, which is $15 \mathrm{~m}$ away from the side of the foundation pit. In case 2, the maximum settlement of the soil surface on the west side of the foundation pit is $-15.600 \mathrm{~mm}$, which is $20 \mathrm{~m}$ away from the side of the foundation pit; The maximum settlement of the east soil surface is $-15.913 \mathrm{~mm}$, which is $15 \mathrm{~m}$ away from the foundation pit. The maximum settlement of soil surface is about $15.0 \mathrm{~mm}$. The maximum settlement of soil surface remains unchanged $(15 \mathrm{~m}$ in the West and $20 \mathrm{~m}$ in the East). The maximum settlement of soil surface is about $0.029 \%$ of the excavation depth of $51.630 \mathrm{~m}$ and $67 \%$ of the maximum horizontal displacement of diaphragm wall. The maximum settlement of soil surface is $20 \mathrm{~m}$ away from the edge of foundation pit, It is about 0.4 times of the excavation depth of $51.630 \mathrm{~m}$.

From the comparison of the two conditions, it can be seen that compared with condition 1, the maximum 
TABLE 13: The corresponding depth of maximum horizontal displacement of diaphragm wall during the 10th excavation under two working conditions.

\begin{tabular}{|c|c|c|c|c|}
\hline \multirow[b]{2}{*}{ Working conditions } & \multicolumn{2}{|c|}{ Diaphragm wall (west) } & \multicolumn{2}{|c|}{ Diaphragm wall (east) } \\
\hline & $\begin{array}{c}\text { Maximum } \\
\text { horizontal displacement } \\
(\mathrm{mm})\end{array}$ & $\begin{array}{l}\text { The depth } \\
\text { of diaphragm } \\
\text { wall }(\mathrm{m})\end{array}$ & $\begin{array}{c}\text { Maximum } \\
\text { horizontal displacement } \\
(\mathrm{mm})\end{array}$ & $\begin{array}{c}\text { The depth of diaphragm } \\
\text { wall }(\mathrm{m})\end{array}$ \\
\hline $\begin{array}{l}\text { Suspended foot diaphragm wall } \\
\text { (working condition 1) }\end{array}$ & 7.738 & -36.66 & -23.497 & -38.99 \\
\hline $\begin{array}{l}\text { Suspended foot diaphragm wall } \\
\text { (reinforcement) } \\
\text { (Working condition 2) }\end{array}$ & 8.143 & -34.37 & -22.665 & -38.99 \\
\hline
\end{tabular}

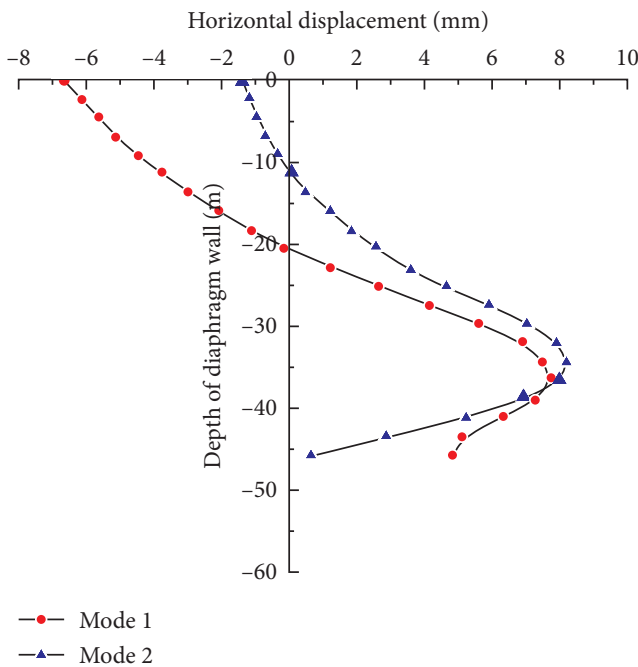

(a)

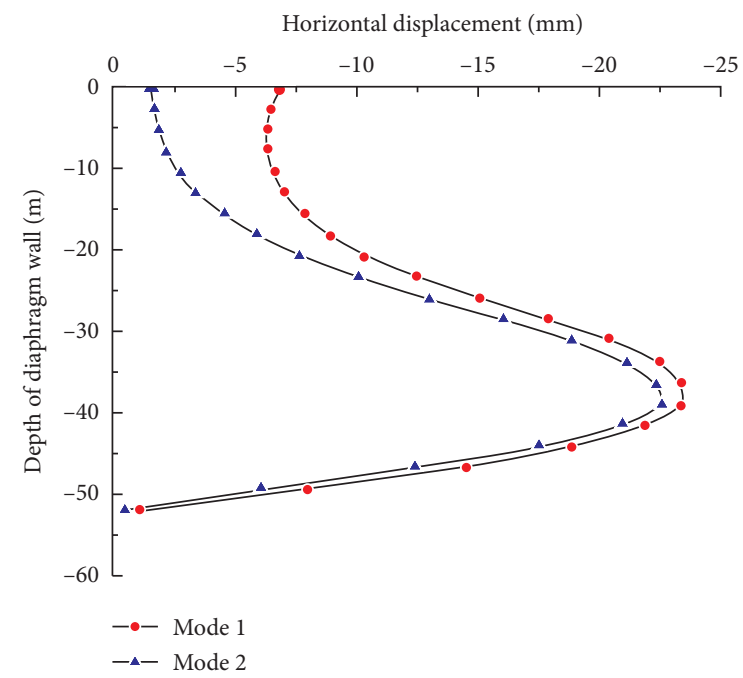

(b)

Figure 15: The horizontal displacement curve of diaphragm wall. (a) West wall, (b) east wall.

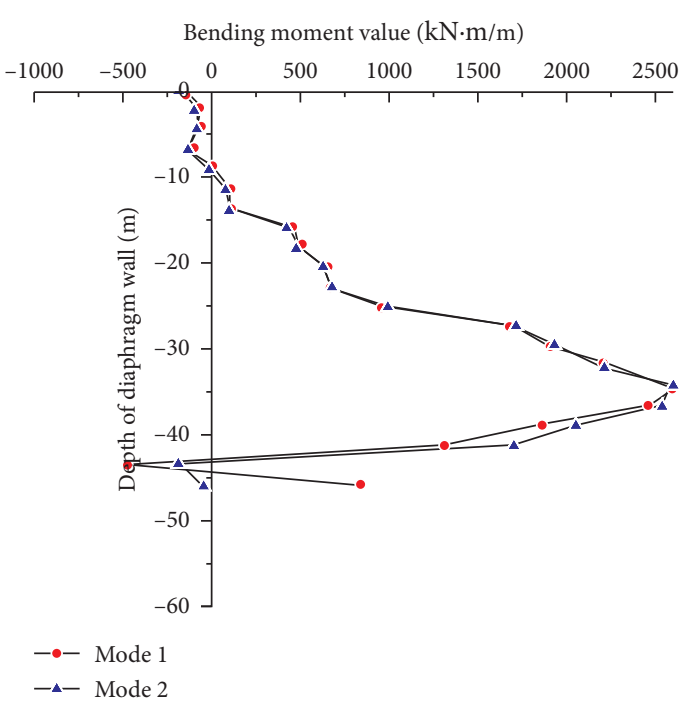

(a)

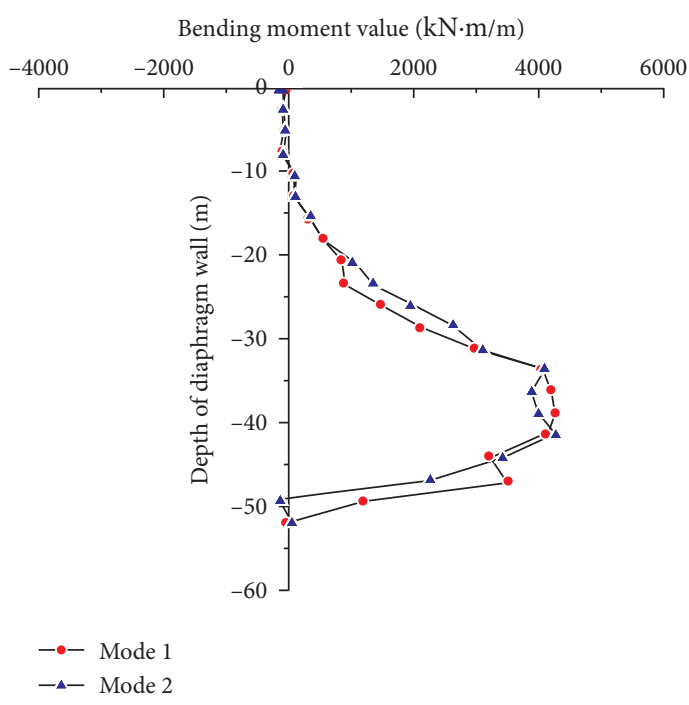

(b)

FIGURE 16: The bending moment diagram of diaphragm wall. (a) West wall, (b) east wall.

settlement of soil surface on both sides of the East and the West decreases by $1.5 \sim 3.0 \mathrm{~mm}$ in condition 2 , which is due to the effective restraint effect of the anchor rod. The maximum settlement position of soil surface on the west side moves to $20 \mathrm{~m}$ away from the edge of the foundation pit, while the maximum settlement position of soil surface on the 
TABLE 14: The corresponding depth of maximum bending moment of diaphragm wall during the 10th excavation under two working conditions.

\begin{tabular}{|c|c|c|c|c|}
\hline \multirow[b]{2}{*}{ Working conditions } & \multicolumn{2}{|c|}{ Diaphragm wall (west) } & \multicolumn{2}{|c|}{ Diaphragm wall (east) } \\
\hline & $\begin{array}{c}\text { Maximum } \\
\text { bending } \\
\operatorname{moment}(\mathrm{kN} \cdot \mathrm{m} / \mathrm{m})\end{array}$ & $\begin{array}{l}\text { The depth } \\
\text { of diaphragm } \\
\text { wall }(\mathrm{m})\end{array}$ & $\begin{array}{c}\text { Maximum } \\
\text { bending } \\
\text { moment }(\mathrm{kN} \cdot \mathrm{m} / \mathrm{m})\end{array}$ & $\begin{array}{l}\text { The depth of diaphragm } \\
\text { wall(m) }\end{array}$ \\
\hline $\begin{array}{l}\text { Suspended foot diaphragm wall } \\
\text { (working condition 1) }\end{array}$ & $2596.608 /-469.726$ & $-34.37 /-43.53$ & $4251.651 /-42.949$ & $-38.99 /-51.98$ \\
\hline $\begin{array}{l}\text { Suspended foot diaphragm wall } \\
\text { (reinforcement) } \\
\text { (Working condition 2) }\end{array}$ & $2576.597 /-191.356$ & $-34.37 /-43.53$ & $4239.727 /-168.822$ & $-41.58 /-49.38$ \\
\hline
\end{tabular}

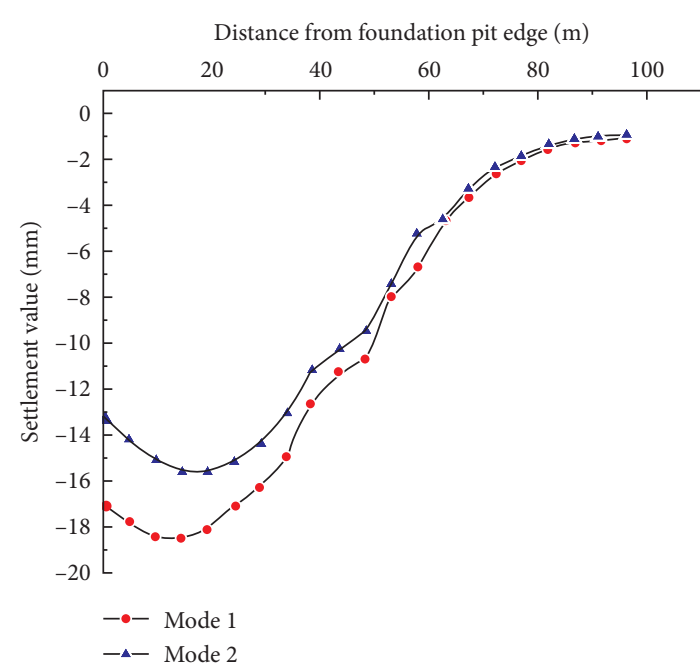

(a)

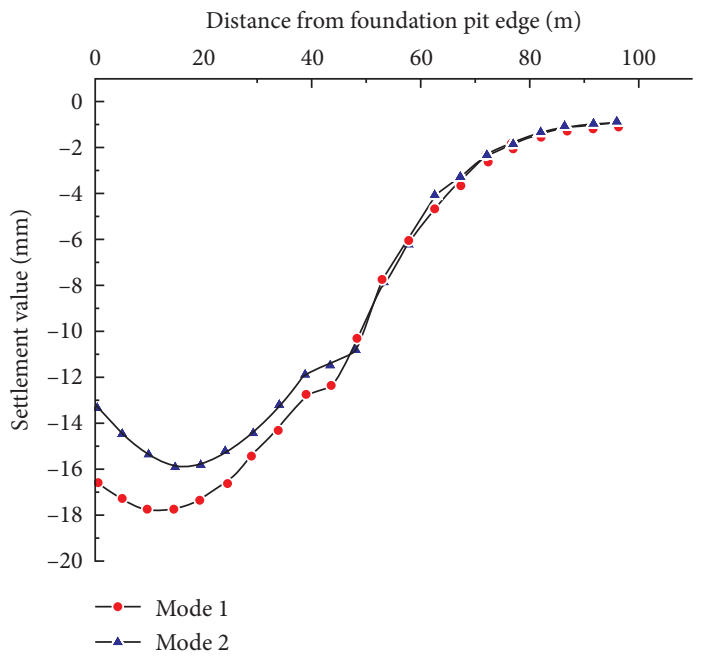

(b)

FIGURE 17: The curve of surface subsidence. (a) West wall, (b) east wall.

TABLE 15: Summary of corresponding positions of maximum ground settlement during the 10th excavation under two working conditions.

\begin{tabular}{|c|c|c|c|c|}
\hline \multirow[b]{2}{*}{ Working conditions } & \multicolumn{2}{|c|}{ Diaphragm wall (west) } & \multicolumn{2}{|c|}{ Diaphragm wall (east) } \\
\hline & $\begin{array}{c}\text { Maximum } \\
\text { settlement }(\mathrm{mm})\end{array}$ & $\begin{array}{l}\text { Distance from } \\
\text { foundation pit edge }(\mathrm{m})\end{array}$ & $\begin{array}{c}\text { Maximum } \\
\text { settlement }(\mathrm{mm})\end{array}$ & $\begin{array}{l}\text { Distance from } \\
\text { foundation pit edge }(\mathrm{m})\end{array}$ \\
\hline $\begin{array}{l}\text { Suspended foot diaphragm wall (working } \\
\text { condition 1) }\end{array}$ & -18.419 & 15.00 & -17.778 & 15.00 \\
\hline $\begin{array}{l}\text { Suspended foot diaphragm wall } \\
\text { (reinforcement) (working condition 2) }\end{array}$ & -15.600 & 20.00 & -15.913 & 15.00 \\
\hline
\end{tabular}

east side remains unchanged. The results show that the settlement curves of soil surface under two conditions increase first, then decrease, and finally tend to be stable with the distance from the foundation pit edge, showing a "groove" curve, and the surface settlement deformation laws of the east and west sides are basically the same.

\section{Conclusion}

In this paper, numerical simulation method is used to study the construction effect of top-down construction method for deep and large foundation pit with underlying inclined rock surface. The horizontal displacement of diaphragm wall, bending moment of diaphragm wall and ground settlement deformation of foundation pit with suspended foot diaphragm wall and anchor bolt locking foot diaphragm wall are analyzed respectively.

(1) When the foundation pit of hanging foot ground connecting wall is excavated by top-down construction method, the horizontal displacement curve of hanging foot ground connecting wall is in the shape of "small at both ends and large in the middle." With the excavation of the foundation pit, the position of the maximum horizontal displacement of the diaphragm wall gradually moves downward, and the maximum positive moment of the diaphragm 
wall is greater than the maximum negative moment. The maximum surface settlement is located $15 \mathrm{~m}$ away from the edge of the foundation pit, which is about 0.3 times the final excavation depth of the foundation pit. The horizontal displacement, bending moment and surface settlement of the hanging foot diaphragm wall decrease with the increase of the rock depth. When the rock depth increases to a certain extent, the effect of continuously increasing the rock depth is no longer obvious. Therefore, in the actual project, the appropriate rock depth is selected on the premise of ensuring the safety of the foundation pit and reducing the cost.

(2) When the foundation pit is excavated by the topdown construction method, the horizontal displacement curve of the ground wall is in the shape of "small at both ends and large in the middle." Compared with the hanging foot ground wall, the displacement, bending moment deformation and surface settlement of the hanging foot ground wall are effectively controlled under the action of the anchor bolt. The horizontal displacement, bending moment value and surface settlement of the hanging foot diaphragm wall decrease with the downward movement of the anchor bolt anchorage position. The addition of anchor bolts can effectively reduce the deformation of the foundation pit, but the anchor position needs to be set reasonably, otherwise, it will not achieve the purpose of effectively reducing the deformation, but also increase the cost. Therefore, the anchor position should be properly selected on the premise of ensuring the safety and stability of the foundation pit.

\section{Data Availability}

The data used to support the findings of this study are available from the corresponding author upon request.

\section{Conflicts of Interest}

The authors declare that they have no conflicts of interest.

\section{Acknowledgments}

This work was supported by Wenzhou Railway and Rail Transit Investment Co., Ltd, and Shanghai Tunnel Engineering Co., Ltd.

\section{References}

[1] Chinese Academy of Building Sciences, Technical Specification for Building Foundation Pit Support: JGJ120-2012, Chinese Academy of Building Sciences, Beijing, China, 2012, in Chinese.

[2] Y. Huang, W. Guo, H. Xiong, and Y. Xiao, "Waterproofing construction technology for underground engineering of large complex," China Building Waterproofing, no. 13, pp. 37-41, 2016, in Chinese.
[3] R. N. Hwang, B. S. Chen, T. E. Wu, and S. W. Duann, Damage to a Metro Tunnel Due to Adjacent Excavation, Springer, India, 2016.

[4] Y. Arai, O. Kusakabe, O. Murata, and S. Konishi, "A numerical study on ground displacement and stress during and after the installation of deep circular diaphragm walls and soil excavation," Computers and Geotechnics, vol. 35, no. 5, pp. 791-807, 2008.

[5] E. Pujades, J. Carrera, and E. Vázquez-SuÉ, "Hydraulic characterization of diaphragm walls for cut and cover tunnelling," Engineering Geology, vol. 125, pp. 1-10, 2012.

[6] W. Wang and J. Shen, "Design and analysis of "pile wall integration" of foundation pit retaining piles and basement external wall," Journal of geotechnical engineering, vol. 34, pp. 303-308, 2012, in Chinese.

[7] Y. Lou, "Retaining design and monitoring analysis of deep foundation pit on soft soil foundation," Journal of Zhejiang water conservancy Shuitun college, vol. 13, no. 3, pp. 7-8, 2001, in Chinese.

[8] M. S. Caspe, "Surface settlement adjacent to braced open cuts," Journal of the Soil Mechanics and Foundations Division, vol. 92, no. 4, pp. 51-59, 1966.

[9] C.-Y. Ou, B.-Y. Shiau, and I.-W. Wang, "Three-dimensional deformation behavior of the Taipei National Enterprise Center (TNEC) excavation case history," Canadian Geotechnical Journal, vol. 37, no. 2, pp. 438-448, 2000.

[10] C. Y. Ou, J. T. Liao, and H. D. Lin, "Performance of diaphragm wall constructed using top-down method," Journal of Geotechnical and Geoenvironmental Engineering, ASCE, vol. 124, no. 9, pp. 798-808, 1998.

[11] M. Long, "Database for retaining wall and ground movements due to deep excavation," Journal of Geotechnical and Geoenvironmental Engineering, ASCE, vol. 127, no. 33, pp. 203224, 2001.

[12] X. Gong, E. song, and H. Guo, Etc Example of Foundation Pit Engineering, pp. 15-23, China Construction Industry Press, Beijing, China, 2006, in Chinese.

[13] T. C. Kung, "Comparison of excavation-induced wall deflection using top-down and bottom-up construction methods in Taipei silty clay-ScienceDirect," Computers and Geotechnics, vol. 36, no. 3, pp. 373-385, 2009.

[14] Z. Z. Aye, T. Boonyarak, N. Thasnanipan, and S. Chea, "Effects of cut-and-cover tunnel construction on adjacent piles of an overpass in Bangkok soft clay," in Proceedings of the Fourth Geo-China International Conference, Shandong, China, 25 July 2016.

[15] G. B. Liu, R. J. Jiang, C. Ng, and Y. Hong, "Deformation characteristics of a $38 \mathrm{~m}$ deep excavation in soft clay," $\mathrm{Ca}$ nadian Geotechnical Journal, vol. 48, no. 12, pp. 1817-1828, 2011. 